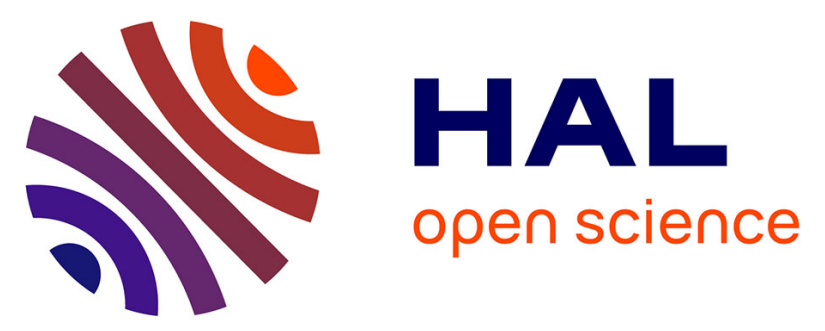

\title{
Active surface faulting or landsliding in the Lower Tagus Valley (Portugal)? A solved controversy concerning the Vila Chã de Ourique site
}

\author{
João Manuel Cabral, Fernando Marques, Paula Figueiredo, Luís Matias
}

\section{To cite this version:}

João Manuel Cabral, Fernando Marques, Paula Figueiredo, Luís Matias. Active surface faulting or landsliding in the Lower Tagus Valley (Portugal)? A solved controversy concerning the Vila Chã de Ourique site. Journal of Seismology, 2010, 15 (2), pp.215-234. 10.1007/s10950-010-9221-8 . hal00651633

\section{HAL Id: hal-00651633 \\ https://hal.science/hal-00651633}

Submitted on 14 Dec 2011

HAL is a multi-disciplinary open access archive for the deposit and dissemination of scientific research documents, whether they are published or not. The documents may come from teaching and research institutions in France or abroad, or from public or private research centers.
L'archive ouverte pluridisciplinaire HAL, est destinée au dépôt et à la diffusion de documents scientifiques de niveau recherche, publiés ou non, émanant des établissements d'enseignement et de recherche français ou étrangers, des laboratoires publics ou privés. 


\title{
Active surface faulting or landsliding in the Lower Tagus Valley (Portugal)? A solved controversy concerning the Vila Chã de Ourique site
}

\author{
João Cabral $^{1}$, Fernando Marques ${ }^{2}$, Paula Figueiredo ${ }^{1}$, Luís Matias ${ }^{3}$ \\ ${ }^{1}$ Geology Department, Faculty of Sciences, and LATTEX/Instituto Dom Luiz, \\ Lisbon University, Ed. C6, $2^{\circ}$ Piso, Campo Grande, 1749-016, Lisboa, \\ Portugal, ${ }^{2}$ Geology Department, Faculty of Sciences, and CGUL, Lisbon \\ University, Ed. C6, $3^{\circ}$ Piso, Campo Grande, 1749-016, Lisboa, Portugal; \\ ${ }^{3}$ Department of Geographic Engineering, Geophysics and Energy, Faculty of \\ Sciences, and CeGUL/Instituto Dom Luiz, Lisbon University, Ed. C8, Campo \\ Grande, 1749-016, Lisboa \\ ${ }^{1} 00351217500349$ \\ ${ }^{1} 00351217500064$ \\ 1jcabral@fc.ul.pt
}

\begin{abstract}
The Lower Tagus Valley has experienced significant (M 6-7) historical seismicity, evidencing the presence of seismogenic faults. These are still deficiently known due to the low strain rates and the recent alluvial sedimentation of the Tagus River that buries most of the structures, though Paleoseismic evidence was allegedly found by a research team in the Tagus valley, at a site $60 \mathrm{~km}$ $\mathrm{N}$ of Lisbon, near Vila Chã de Ourique (VCO). According to this team, trenching at the VCO site exposed an active thrust fault, evidencing the surface rupture of a large earthquake that occurred in 1531. Our studies performed at this site, comprising field observations with a reappraisal of the trench outcrops previously excavated, borehole drilling, soil mechanics laboratory testing and seismic reflection acquisition, pointed to the alternative interpretation that the outcropping structures are gravitational and not of tectonic origin. The interpretation of new outcrops crosscutting the structures exposed at the trenches, as well as newly acquired high resolution seismic reflection data, definitely exclude the active thrust fault explanation and support a gravitational slip model for all the observed structures. Gravitational slip in the river bank slope was promoted by low shear strength clays and high pore water pressure coupled with slope toe river erosion. Gravitational slides must have occurred prior to development of the present sedimentation level of the Tagus alluvial plain, which was attained in the last few thousand years as indicated by borehole data and estimations of sedimentation rates.
\end{abstract}

Keywords: surface faulting, landsliding, paleoseismicity, Lower Tagus Valley, mainland Portugal 
The study area is located in central-western Portuguese mainland (W Iberia), in the Lower Tagus Valley (LTV). The LTV corresponds to the lower reach of the Tagus River, forming a conspicuous NE-SW morphological lineament, and comprises the densely populated and highly developed area of Lisbon (Figure 1). Earthquakes that caused severe damage and many casualties have affected this region, making seismic hazard evaluation a major regional issue.

According to some authors (Fonseca et al. 2000a,b, 2001; Vilanova 2003; Vilanova and Fonseca 2004), paleoseismic evidence was found at a site on the right margin of the Tagus river $60 \mathrm{~km} \mathrm{~N}$ of Lisbon, at Vila Chã de Ourique (VCO) (Figure 1), where four trenches were excavated. According to these authors, trenching at the VCO site revealed an active thrust fault, which was considered a source of the regional historical seismicity, evidencing the surface rupture of a large earthquake that severely affected the LTV region in 1531.

However, a reconnaissance trip to the VCO trenches showed us that the active surface faulting interpretation of Fonseca and collaborators (op. cit.) might be wrong, requiring further studies at the site. Our complementary research comprised field observations, including a reappraisal of the trench outcrops previously excavated by Fonseca and collaborators, borehole drilling, sample collection, and seismic reflection acquisition, as well as laboratory characterization and shear strength testing of the collected samples.

Based on our observations, we have proposed an alternative interpretation which considered that the structures exposed in the VCO trenches probably were of gravitational and not of tectonic origin (Cabral and Marques 2001; Cabral et al. 2002, 2003). This controversy has been recently referenced by McCalpin and Carver (2009, p. 366) as "a recent European example (that) illustrates the ambiguity (between landslide toe thrusts and true thrust faults), and the result on seismic hazard assessment". The authors conclude that "... at this time the ambiguity remains whether the fault exposed in the Portuguese trench is tectonic and seismogenic, or nontectonic and nonseismogenic".

The present work intends to resolve this issue based upon a refinement of previously performed slope stability analysis, newly acquired seismic data and new observations at the VCO site. Actually, a new seismic reflection profile was 
acquired transversely to the expected prolonging of the structures encountered in the trenches, employing higher natural frequency geophones $(28 \mathrm{~Hz}$ instead of the previous $10 \mathrm{~Hz}$ ) for tentatively improving the quality of the seismic section. Also, detailed observations were performed at new outcrops that were exposed at the VCO site as a result of works for building a railway underground passage, which crosscut the structures exposed at the trenches allowing a view further in depth.

As discussed below, the seismic data and the new outcrops, where an eastwards steeply dipping slip surface was exposed, preclude the thrust fault interpretation of the slip surfaces identified in the trench walls, proposed by Fonseca and collaborators, and strongly support a landslide model for all the observed structures.

\section{Regional geological setting and seismicity}

The LTV is located mostly in the Lower Tagus Cenozoic Basin (LTCB), a NE-SW elongated tectonic depression filled with Cenozoic sediments. This basin evolved since the Eocene as a transpressive foredeep related to the tectonic inversion of the former, extensional Mesozoic Lusitanian Basin (LB), located to west, mainly under the action of a NW-SE Miocene compression (Figure 2) (Ribeiro et al. 1990; Cabral 1995; Cabral et al. 2003; Carvalho 2003).

The LTCB comprises up to about $2000 \mathrm{~m}$ of Tertiary (Paleogene to Pliocene) sediments, and also a thick (up to $70 \mathrm{~m}$ ) Upper Pleistocene to Holocene alluvial cover due to Wurmian drainage incision followed by aggradation. Entrenchment of the fluvial network and the presence of Quaternary terraces provide evidence of reversal of the regional subsidence to uplifting since the Early Pleistocene (Cabral 1995).

The Cenozoic evolution of the LTCB was controlled by the NNE-SSW main structural trend of the LB. Tectonic inversion of former normal faults generated ESE verging reverse faults, as those that limit the LTCB on the NW side, placing Mesozoic rocks of the LB, to the NW, over Cenozoic sediments of the LTCB, to the SE. A major example is the Vila Franca de Xira fault (Cabral et al. 2003; Carvalho et al. 2006, 2008) (Figure 2).

Surface geology, seismic reflection and potential field data (gravimetric and geomagnetic) point to further complexity, evidencing structural lows and 
highs that are delimited by WNW-ESE to NW-SE faults, transverse to the LTV trend, in addition to the NNE-SSW "longitudinal" faults (Cabral 1995; Rasmussen et al. 1998; Cabral et al. 2003; Carvalho 2003; Carvalho et al. 2006, 2008). This indicates the presence of a segmented fault system, with NNE stepped fault segments evidencing Neogene vertical offsets (mostly high angle reverse) in the framework of overall left-lateral transpression, which are linked by WNW faults also accommodating significant vertical offsets.

According to data from borehole breakouts and earthquake focal mechanisms, the maximum horizontal compressive stress presently trends NW-SE to WNW-ESE (Ribeiro et al 1996; Borges et al. 2001).

Regional seismicity comprises relatively distant events, as the 1755 earthquake, one of the largest historical events ever described (estimated $\mathrm{M}_{\mathrm{W}} \geq 8.5$ ), which was generated in the broad deformation zone of the EurasiaAfrica plate boundary (Grácia et al. 2003; Terrinha et al. 2003; Zitellini et al. 1999, 2001, 2004). The study region also experiences a significant local seismicity, attested by the occurrence of moderate to large historical earthquakes, as in 1344, 1531 and 1909, with estimated magnitudes ranging from 6 to 7 (Martins and Mendes Victor 2001; Mezcua 1982; Moreira 1985, 1991; Oliveira 1986) (Figure 3a,b).

The 1344 event in particular, but also the earthquake in 1531, are poorly located due to the scarcity of historical descriptions, being positioned in the LTV based upon the destruction that they produced in the Lisbon area. The 1531 event caused severe damage and many casualties in the town of Lisbon, reaching an intensity of IX MM (Moreira 1984; Mezcua 1982, Oliveira 1986; Henriques et al. 1988; Justo and Salwa 1998) (Figure 3a).

The April $23^{\text {rd }} 1909$ earthquake was definitely located NE of Lisbon, near Benavente, where it was felt with a maximum intensity of IX (MM) (Figure 3b), causing several fatalities. It reached $\mathrm{M}_{\mathrm{W}}=6$ (Teves-Costa et al. 1999), and a focal mechanism solution has been calculated by Stich et al. (2005) indicating reverse faulting with nodal planes trending ENE-WSW. Concerning the instrumental seismicity, the earthquake activity in the study area has been relatively low and diffuse as shown in Figure 3c. The earthquake dataset for the period considered (1960 to 2007) is nearly complete for $M \geq 2$, with only $14 \mathrm{M} \geq 4$ earthquakes ( $\mathrm{M}=4.5$ maximum) occurring in that period. 
The regional seismicity clearly evidences the presence of active seismogenic faults, and detailed research has been conducted for characterizing the regional seismotectonics. Studies from several authors show the importance of the local seismic sources to the seismic hazard of the LTV area (e.g. Peláez et al. 2002; Vilanova et al. 2003; Vilanova and Fonseca 2004; Cabral et al. 2003, 2004; Carvalho et al. 2006, 2008), although they are still deficiently known due to the low strain rates and the thick Tertiary and Quaternary sedimentary cover that conceals most of the active faults, rooted in the Mesozoic and Paleozoic basement rocks located underneath.

The low instrumental seismicity, the poor earthquake location and the depth at which the earthquakes are generated in the study region also prevent a reliable relationship between the earthquakes and the faults recognized at the ground surface or in the uppermost $2-3 \mathrm{~km}$ of the crust, where they cut through the Mesozoic and Cenozoic rocks of the Lusitanian and Lower Tagus basins, respectively. The geometry of the Tertiary sedimentary basin may also play an important role on local energy enhancement and site-effects, masking the relationship between the historical events location based on seismic intensity studies and the earthquake sources.

\section{Geomorphologic, stratigraphic and structural setting of the VCO site}

The landscape in the study region shows wide and levelled interfluves evidencing the presence of a rather uniform plateau incised by the drainage network, which correlates with an erosion surface of probable Lower Quaternary age that occurs along most of the Lower Tagus sedimentary basin (Martins and Barbosa 1992; Martins 1999; Cabral et al. 2004) (Figure 4). This erosion surface relates to the first incision of the regional drainage network on a former, Piazencian, alluvial plain, and so it may register tectonic deformation accumulated since the Lower Pleistocene.

In the VCO area, this plateau is at an elevation of $60-70 \mathrm{~m}$, which is 30 to $40 \mathrm{~m}$ lower than its common height of approximately $100 \mathrm{~m}$. The lower elevation of the erosion surface and a gentle tilt towards the south reveal deformation related to a major active structure located to the west - the Azambuja fault, which 
presents a conspicuous NNE-SSW trending scarp that gets progressively higher southwards (Cabral et al. 2004) (Figure 4).

A striking geomorphic feature of the VCO area is the prominent, though sinuous and discontinuous steep slope that extends for approximately $25 \mathrm{~km}$ along the right bank of the Tagus river valley, from Azambuja, at the south, to Santarém, at the north (Figures 4 and 5). This slope was interpreted as a fault scarp by Fonseca and collaborators (Fonseca et al. 2000a,b, 2001; Vilanova 2003; Vilanova and Fonseca 2004) and it was thus a major incentive for field prospecting. Trenching was then performed by these authors based on the observation of anomalous structures at the toe of the riverbank slope at the VCO site, where an active thrust fault was allegedly exposed.

Besides the fault scarp evidence for active faulting, this tectonic activity should also be expressed on the regional landscape by localized uplifting. However, the general trend of the regional plateau described above, which is the older geomorphic reference recognizable in the area, does not reveal any restricted rising related to an active thrust fault at the VCO area. Actually, the plateau is locally lower than its typical regional elevation, and slightly tilted southwards, as it is positioned in the downthrown block of the Azambuja fault, referred above. As a result, the NE-SW to NNE-SSW slope bordering the Tagus valley in the study area gradually decreases height from approximately $70 \mathrm{~m}$, at the NE, to approximately $20 \mathrm{~m}$ at the SW (near Azambuja), reflecting the southward tilting of the erosion surface located at the top.

The presence of a major active thrust fault near the VCO site should also produce fault-related deformation on the local sediments, such as tilting, folding and/or fracturing by subsidiary faults. However, the geological structure at VCO and surrounding area is simple and regular: Miocene sands, clays, marls and some intercalated limestone beds, of Vallesian (Tortonian) age, rest sub-horizontally, with Pliocene sands lying unconformably on the top, partially truncated by the regional erosion plateau. At the base of the steep slopes generated by river incision, they contact with clayey sediments of the alluvial plain of the Tagus River and of some tributaries. The Neogene sedimentary units are slightly tilted, accompanying the morphological gradient towards the south, and do not show any evidence of significant local tectonic deformation. 
Accordingly, we interpret the prominent slope that margins the Tagus entrenchment of around $100 \mathrm{~m}$ since Lower Quaternary (Cabral 1995; Martins and Barbosa 1992; Martins 1999), corresponding mainly to a cliff carved by basal fluvial erosion. Landslide activity is also an important evolutionary process of this slope, very well documented in several locations along its strike, especially near Santarém city (e.g. Oliveira 1973, Coelho 2001), 9km NE of the VCO site.

The dominant action of erosion is supported by the rather sinuous trend of the slope and by the distinct profiles that it shows along strike, being steepest at the northern sector, in the vicinity of the VCO site (Figure 4). Map view suggests that the stronger dip of the slope in this sector is probably due to slope retreat by lateral fluvial erosion at the concave margin of a sinuosity of the Tagus river channel, under conditions of deeper incision related to a Wurmian glacio-eustatic sea level low stand.

Actually, data from boreholes drilled for various purposes (underground water exploitation, geotechnical prospecting, and scientific exploration) in the Tagus alluvial plain show that the Late Pleistocene to Holocene alluvial cover of the Tagus River is very thick, reaching a depth of down to approximately $-70 \mathrm{~m}$ in the downstream sector of the valley, near Lisbon. This is due to a time of deeper incision of the Tagus River related to a lower base-level $(-120 \mathrm{~m})$ during the last glacial maximum ( $\sim 20,000$ yrs ago), followed by aggradation in response to climate change and rapid base-level rise, which occurred until $\sim 7,000$ yrs ago, when sea level stabilized (Vis et al. 2008).

The thickness of this alluvial cover progressively reduces upstream, though it still exceeds $32 \mathrm{~m}$ approximately $1.5 \mathrm{~km}$ east of the VCO site, as evidenced in a borehole drilled in the area (core VAL, end depth of $32.20 \mathrm{~m}$; Vis 2009). Four samples collected at different depths in this core were dated (Vis, $o p$. cit.). The deepest one (27.48-27.53 m) was radiocarbon dated at 10,190-9,740 cal. $\mathrm{BP}$, giving an average aggradation rate of $2.7-2.8 \mathrm{~mm} / \mathrm{yr}$ roughly in the Holocene. In a borehole drilled in the alluvial plain near the base of the slope at VCO (borehole 0501.042, Benfica do Ribatejo section; Vis, 2009), the Quaternary sediments exceed $9.10 \mathrm{~m}$ (reached depth). A sample collected from a depth of $2.45 \mathrm{~m}$ in this borehole was dated at 2720-2360 cal BP (Vis, op. cit.), giving an average aggradation rate of $0.88-1.01 \mathrm{~mm} / \mathrm{yr}$. In another borehole located 
approximately $500 \mathrm{~m}$ further east (borehole 0501.041, Vis 2009), the Tagus alluvial sediments exceed $13.90 \mathrm{~m}$ (reached depth), and a sample collected from a depth of $11.65 \mathrm{~m}$ was dated at $6510-6300 \mathrm{cal} \mathrm{BP}$, giving an average aggradation rate of $1.77-1.83 \mathrm{~mm} / \mathrm{yr}$. A rather similar average sedimentation rate of $2.2 \mathrm{~mm} / \mathrm{yr}$ was estimated for the last $3.4 \mathrm{ka}$, based upon a $7.4 \mathrm{~m}$ core drilled in the alluvial plain $2 \mathrm{~km}$ ESE of the VCO site (Ramos et al. 2002).

This geomorphologic evolution is consistent with the trend of the longitudinal profiles of some tributary streams in the VCO area, which show knick points produced by downstream entrenchment in response to the above referred processes of recent fast entrenchment of the Tagus River in relation to a lower Wurmian sea level, and also to the coeval bank-slope retreat. This interpretation is supported by the slope of the longitudinal profiles of the creeks, evidencing downstream steepening related to a lower base level, followed by gradient reduction due to the recent aggradation near their mouth (Figure 6)

The Holocene aggradational effect is clearly expressed in the lower stretch of the tributaries by enlarged alluvial plains and low longitudinal dips. In these downstream stretches, the valley slopes show profiles that can be related to the Wurmian period of deeper incision, and the steeper longitudinal profiles located immediately upstream also correlate with the same lower base level, strongly supporting the erosional interpretation of the convex stream profiles (Figure 6).

\section{The VCO trenching site}

The VCO trenching site is located at the toe of the above referred NE-SW steep slope, at the right bank of the Tagus river, where it is intersected by a tributary valley that creates a wedge-shaped cliff pointing southwards. By the toe of this slope passes the most important railway line in Portugal.

Intense instability affects a $300 \mathrm{~m}$ long slope section located NNE of the VCO site (including fissuring, slide scars, steep down-dip profile, ongoing landsliding), and the need to insure safe operation of the railway line induced the construction of engineering slope stabilization works which include drainage, toe retaining walls and extensive surface modelling. These stabilization works suffered considerable deformations during the 2000/2001 winter and severe damage by excessive slope deformation during the 2005/2006 winter, which 
caused subsequent extensive repair works of the slope and the railway line platform.

The gravitational instability is promoted by the slope profile, the presence of a low shear strength Miocene clayey and silty unit at its middle and lower section, overlaying and concealing coarse sands of high permeability where seasonal high pore water pressures are generated, with water head frequently above ground level at the lower part of the slope.

We performed detailed observations at the trenches that Fonseca and collaborators excavated at the VCO site, near the base of the presumed fault scarp. As they state (Fonseca et al. 2000a,b, 2001; Vilanova 2003; Vilanova and Fonseca 2004) several striated slip surfaces outcropped at the trench walls, generally dipping towards the Northwest and designing an imbricate geometry. Some of them presented very low dips and even reversed their plunge. The slip surfaces, particularly those cut on the Miocene clayey and silty unit, presented abundant north-south striations, pointing directly to the nearest steep slope segment, which designs a free face cut on the harder Miocene marls immediately north of the trench site, supporting a gravitational origin (Figure 7).

To assess the possibility of occurrence of landslides which could explain the features observed in the trenches, slope stability analysis were performed using: 1) accurate topography survey of the slope using a total station (Figure 7), completed by a detailed survey carried out for the 2006 engineering works; 2) assessment of the geometry and position of internal shear planes by purpose made boreholes with continuous sampling and field observations; 3) soil properties measured in laboratory testing for index and direct shear strength. 4) limit equilibrium methods for circular and fully specified failures;

A preliminary slope stability analysis was performed using the Bishop simplified method (Bishop 1955), with soil properties obtained in laboratory direct shear tests and the geometry of the slope assessed by a detailed topographical survey carried out with a total station. Considering several circular failure surfaces, the results indicated that the landslide hypothesis was highly plausible and could explain the features surveyed at the VCO trenches, namely the northwest dipping striated slip surfaces which are typical features of the down slope end of a circular or near circular failure surface (Cabral and Marques 2001). 
In order to confirm the proposed landslide model, a vertical boring with continuous recovery, $14.6 \mathrm{~cm}$ in diameter, was drilled $20 \mathrm{~m}$ to the north of the trenches, reaching a depth of $18.37 \mathrm{~m}$. A lithological log was constructed and samples were collected for laboratory testing. Several striated surfaces were intersected by the boring, crossing massive clay between the depths of $0.90 \mathrm{~m}$ and $2.10 \mathrm{~m}$. Most of the observed striae were approximately rectilinear with a $90^{\circ}$ pitch (Figures 7 and 8). Slip sense criteria in several of the striated surfaces indicated downthrowing of the hanging wall, which is compatible with gravitational sliding. Two other boreholes were drilled with a hand-auger, one located midway between the previously drilled boring and the trenches, and the other at the lowest point of the trenches floor (Figure 7). The local lithologies were crossed at the expected depths, attending to the previously obtain log, and there wasn't any evidence of fault offset (Cabral et al. 2002, 2003).

The sedimentary sequence crossed by the continuous recovery boring, the small depth at which it intersected the slip surfaces in the Miocene clayey sediments, and the geometry shown by recent slides on the same slope, suggested however that the gravitational sliding interpreted at the trench was shallower and flatter than previously proposed by Cabral and Marques (2001). The geometry of the structures exposed at the outcrops that were opened during the 2006 engineering works at the VCO site confirmed this analysis, and revealed another steep, deeper rooted, slip surface that we also interpret as of gravitational origin.

\section{Interpretation of the new outcrops at the VCO site}

As mentioned above, after the previous research was concluded (Cabral et al. 2002, 2003) new outcrops were uncovered at the VCO site, as a result of the works for building a railway underground passage. These outcrops crosscut the structures that were exposed at the trenches opened by Fonseca and collaborators, allowing a view at further depth and permitting a reappraisal of the previous data and proposed models.

The new outcrops showed a major, southeastwards steeply dipping, slip surface, which puts clayey colluvium in the hanging wall, to the SE, in mechanical contact with whitish Miocene sands in the foot wall, to the NW (Figure 9). In detail, this structure presents a relatively complex geometry, 
showing rather curved and branched, polished and striated slickensides where they penetrate the clayey material. Upwards, this major slip surface progressive reduces dip, merging into another low dip slip surface which apparently accommodates later movements and seals the underlying structure.

The exposed geometry precludes the thrust faulting interpretation of the slip surfaces identified in the trench walls, one of which corresponds to the uppermost slip surface uncovered in the new outcrop (Figure 9), and supports a gravitational slip model for all the observed structures, triggered by high pore water pressure (Figure 10).

The evolutionary stages of the proposed landsliding model are depicted in Figure 11. As schematically shown, the first gravitational slide on the lower, steep surface activated the contact between the former lower slope profile and an overlaying colluvial wedge (Figure 11c, event 6), and must have occurred prior to the development of the present sedimentation level of the Tagus alluvial plain, which was attained in the last few thousand years as indicated by estimations of aggradation rates performed above, based upon borehole data from Ramos et al. (2002) and Vis (2009). At that time, the toe of the slope merged into a narrow erosion pediment which was approximately 7-8 $\mathrm{m}$ below the present alluvial plain (Figure 11a-c), as suggested by the depth to the base of the Recent alluvial infill in borehole II (Fonseca et al, personal communication) (Figures 10 and 11e).

Slip postdates the paleosol that is buried within the colluvial wedge (Ps, at the top of colluvium 1 in Figure 9), as it is tilted towards the slip surface, evidencing a listric geometry. This paleosol outcropped in the trenches opened by Fonseca and collaborators, where two samples were radiocarbon dated, giving an average age of 2,700 yrs BC (Fonseca et al. 2001; Vilanova et al. 2004), corresponding to $4,650 \mathrm{yrs} \mathrm{BP}$.

Considering an average sedimentation rate of about $1.8 \mathrm{~mm} / \mathrm{yr}$ for the alluvial sediments in the last ca. $6.4 \mathrm{ka}$, inferred from data from borehole 0501.041, located approximately $500 \mathrm{~m}$ east of the VCO site (see discussion above), we may deduce a thickness of alluvial aggradation of roughly $8.4 \mathrm{~m}$ since the development of the reference soil horizon, which is coherent with the proposed model. 


\section{Laboratory testing and slope stability analysis}

Laboratory testing of samples of the clay and silts unit indicate that it is mainly composed by high plasticity overconsolidated clays with small carbonate content which corresponds to small nodules of weak and porous limestone (Table 1). The direct shear tests were performed with intact samples, with $0.01 \mathrm{~mm} / \mathrm{min}$ shear velocity, which coupled with the increased permeability of the soil caused by the presence of the limestone nodules, correspond to near drained shear conditions. For each sample a first test was made for peak strength measurement, followed by a residual test in the same direction of the peak test.

The results obtained indicate peak shear strength parameters $c=13 \mathrm{kPa}$, $\phi=19^{\circ}$ (10 tests) and residual strength $\mathrm{c}=5 \mathrm{kPa}, \phi=11.5^{\circ}$ (10 tests) (Figure 12), which can be taken as a close estimate of shear strength drained parameters. The positive cohesion intercept for residual tests may have been caused by the presence of the small limestone nodules, which tend to increase the shear plane roughness and in consequence, to produce slightly increased strength values especially for the test performed at lower normal stress.

The slope stability analysis carried out for the shear planes depicted in Figures 10 and 11e were made using GeoSlope SLOPE/W v.5 software considering circular and fully specified failure surfaces, with the piezometric line slightly above ground, which is a condition likely to occur during heavy or prolonged rainfall, and using Bishop (1955), Jambu (1954) and Morgenstern and Price (1965) limit equilibrium methods (Figure 13). Considering the long term conditions that prevail in these slope failures, residual strength parameters were used.

The results obtained for different failure conditions that cover all the groups of shear planes identified in the VCO trenches, indicate safety factors lower than 1 in heavy or prolonged rainfall periods, and thus landslide triggering is certain in these conditions. This is further supported by the recurrent slope instability events that affected the railway line at VCO: as referred above, the slope sections located northwards were object of various heavy engineering stabilization works, but in spite of these, their intermediate portions, located approximately one hundred metres to NNE, started to move in the 2000/2001 winter, and subsequently the slope drainage system was completely destroyed with heavy deformation of the slope profile in the 2005/2006 winter. 


\section{Seismic reflection data}

In order to confront the models of faulting vs. landsliding, four highresolution seismic reflection profiles (VCO1-4) were first performed at the trenching site, two of them perpendicularly, and the other two parallel to the slope (and presumed fault?) trend, with lengths ranging between 25 and $70 \mathrm{~m}$ (Cabral et al. 2003, Simão 2003) (Figure 14). A hammer was used as energy source, and the $\mathrm{P}$ wave arrivals were registered by $10 \mathrm{~Hz}$, vertical component, geophones. A 24 channels Seistronix RAS-24 Remote Acquisition System was employed for signal transferring and processing.

The quality of the obtained seismic sections was generally poor, possibly due to bad coupling of the geophones, the low level of maximum frequencies provided by the used energy source, and also the low natural frequency of the geophones that were employed $(10 \mathrm{~Hz})$. Particularly in what concerns profile VCO2 and the key line VCO3 (acquired perpendicularly to the studied slope, aligned along one of the trenches and passing at the drilled well location), the resolution was low and there was lack of coherence of reflectors along most of the sections. Yet, profiles VCO1 and VCO4 showed enough coherence to support a reliable geological interpretation (Cabral et al. 2003, Simão 2003).

Line VCO1 was acquired at the alluvial plain east of the Tagus riverbank and parallel to the slope, so that it does not provide direct information concerning the structures under study. But seismic section VCO4 was obtained at the alluvial plain of the small tributary creek located south of the trenches site, crossing the foreseeable prolonging of the tectonic structure proposed by Fonseca et al. (2000b).

In this section, an uppermost almost continuous reflection horizon can be recognized, which is interpreted as the base of the Holocene alluvial infilling, evidencing the absence of surface, or near-surface faulting, for the resolution of the seismic data (estimated at approximately $3 \mathrm{~m}$ ) (Figure 15). The base of this sedimentary cover is located at a two-way travel time (twt) of about $20 \mathrm{~ms}$, corresponding to a depth of approximately $7 \mathrm{~m}$ taking a seismic wave velocity of $700 \mathrm{~m} / \mathrm{s}$ (Simão 2003). Some other reflection horizons are recognizable below, 
most probably corresponding to the bedding of the Miocene sediments. Below $100 \mathrm{~ms}$ twt coherence is poor for allowing a reliable interpretation.

To get further information and improve reliability, another high resolution seismic reflection profile was acquired later (VCO-AB, Figure 15), approximately coincident with the former VCO4 section, using this time higher frequency (28 $\mathrm{Hz}$ ) geophones. The same energy source, geophone layout (1.5 m separation) and acquisition system were used but we obtained a new seismic section with improved resolution on the top $100 \mathrm{~ms}$ TWT. As in the previous section, an upper set of almost continuous reflection horizons is recognized on profile VCO-AB (Figure 16). A sharp, continuous horizon is evident at a depth of approximately 20 ms (twt), which we again interpret as Holocene alluvial infilling. Similarly to the VCO4 section, this reflection horizon identified on the new seismic profile at a depth of ca. $7 \mathrm{~m}$ (for a seismic wave velocity of $700 \mathrm{~m} / \mathrm{s}$ ), and interpreted as the base of the Recent alluvial sediments, doesn't show any evidence of fault displacement, for the resolution of the seismic data, now estimated as approximately $2 \mathrm{~m}$.

\section{Conclusions}

The results of the studies that we have performed at the VCO site, which comprised field reconnaissance, a reappraisal of the trench outcrops previously excavated by Fonseca and collaborators (Fonseca et al. 2000a,b, 2001; Vilanova 2003; Vilanova and Fonseca 2004) and the interpretation of new outcrops meanwhile uncovered at the site, borehole drilling, soil mechanics laboratory testing, slope stability analysis, and seismic reflection acquisition, point to the alternative interpretation that the outcropping structures are gravitational and not of tectonic origin.

The new outcrops that were exposed at the VCO site crosscutting the structures that outcropped at the trenches enabled a view further in depth and increased the knowledge about the local stratigraphy. These new outcrops, where an eastwards steeply dipping slip surface was exposed, together with the refined slope stability analysis, and newly acquired high resolution seismic reflection data, all preclude the thrust fault interpretation of the slip surfaces identified in the trench walls and support a gravitational slip model for all the observed structures. 
The gravitational slip was mainly caused by the presence of low shear strength clays and triggered by high pore water pressure, coupled with slope toe river erosion giving rise to a steep profile. We do not discard the possibility that the studied landslide was activated by an earthquake, though, as explained in the text, the slope is unstable enough to slide without the action of earthquake shaking. The gravitational slides must have occurred prior to development of the present sedimentation level of the Tagus alluvial plain, which was attained in the last few thousand years as indicated by borehole data and estimations of sedimentation rates.

The fact that we interpret the structures identified in the VCO site as non tectonic does not rule out the presence of an active tectonic structure in the area. Actually, there probably is a major NNE-SSW trending active fault to the East of the VCO site, belonging to the Lower Tagus Valley fault system, which is concealed beneath the late Pleistocene to Holocene alluvial fill of the Tagus River. The presence of this active fault is suggested by morphotectonic and hydrogeological data (Cabral 1995; Mendonça and Cabral 2003; Martins et al. 2009) and is still to be confirmed.

\section{Acknowledgments}

Financial support for this work was provided by Fundação para a Ciência e a Tecnologia in the scope of projects Seismic Hazard Evaluation of the Lower Tagus Valley

(POCTI/CTA/11178/1998 - SHELT), Seismotectonics GIS Database for Mainland Portugal (POCI/CTE-GIN/58250/2004 and Paleoseismological Study of Active Faults in Mainland Portugal (PTDC/CTE-GIN/66283/2006). We thank Nuno Simão for his help in the acquisition and processing of the seismic profiles. We are grateful to Prof. K. Reicherter and an anonymous reviewer for their careful reviews and comments that significantly improved the manuscript.

\section{References}

Bishop AW (1955) The use of the slip circle in the stability analysis of slopes. Geotechnique 1:717

Borges JF, Fitas AJS, Bezzeghoud M, Teves-Costa P (2001) Seismotectonics of Portugal and its adjacent Atlantic area. Tectonophysics 337:373-387 
Cabral J (1995) Neotectónica em Portugal Continental. Memórias do Instituto Geológico e

Mineiro, 31, Lisboa

Cabral J, Marques F, Figueiredo P, Simão N, Matias L (2003) New data on the active surface faulting vs. landsliding controversy concerning the Vila Chã de Ourique site (Lower Tagus Valley). Ciências da Terra N.Esp. 5, VI Congresso Nacional de Geologia, Junho 2003, UNL, Caparica, D10-D13 (CD-ROM)

Cabral J, Marques F, Figueiredo P (2002) Paleoseismicity evidence in the Lower Tagus Valley (Lisbon Region)? An example of misinterpretation of geological data. $3^{\text {a }}$ Assembleia LusoEspanhola de Geodesia e Geofísica, Univ. Polit. de Valencia, 4-8 Fev. 2002, Proceedings I, 386389

Cabral J, Ribeiro P, Figueiredo P, Pimentel N, Martins A (2004) The Azambuja fault: An active structure located in an intraplate basin with significant seismicity (Lower Tagus Valley, Portugal).

J. Seismol. 8:347-362

Cabral J, Marques FMSF (2001) Paleoseismological studies in Portugal: Holocene thrusting or landslide activity? EOS Transactions 82:351-352

Carrilho F, Nunes JC, Pena J, Senos ML (2004) Catálogo Sísmico de Portugal Continental e Região Adjacente para o período 1970-2000, Instituto de Meteorologia, Lisboa, ISBN 972-9083$12-6$

Carvalho J (2003) Sísmica de alta resolução aplicada à prospecção, geotecnia e risco sísmico. $\mathrm{PhD}$ Dissertation, Universidade de Lisboa

Carvalho J, Cabral J, Gonçalves R, Torres L, Mendes-Victor L (2006) Geophysical Methods Applied to Fault Characterization and Earthquake Potential Assessment in the Lower Tagus Valley, Portugal. Tectonophysics 418:277-297

Carvalho J, Rabeh T, Cabral J, Carrilho F, Miranda JM (2008) Geophysical characterization of the Ota-Vila Franca de Xira-Lisbon-Sesimbra fault zone, Portugal. Geophys J Int 174:567-584 Coelho AG (2001) Historia de las laderas de Santarém (Portugal). Problemas de estabilización de laderas alcantiladas coronadas por un estrato rocoso. V Simposio Nacional sobre Taludes y Laderas Inestables, Vol. I, CEDEX, Madrid

Fonseca FBD, Meghraoui M, Bosi, V, Cardoso JL, Oosterbeek L (2000a) ECGS Field Trip to the Lower Tagus Valley, Portugal, Lisbon, 9th of September 2000, Guide Book, ECGS, FCT, IST, Lisbon

Fonseca FBD, Bosi V, Vilanova SP, Meghraoui M (2000b) Investigations unveil Holocene thrusting for onshore Portugal. EOS Transactions 81:412-413

Fonseca, FBD, Bosi V, Vilanova SP and Meghraoui M (2001) Paleoseismological studies near Lisbon: Holocene thrusting or landslide activity? - Reply. EOS Transactions 82:352-353

Gràcia, E, Dañobeitia, J, Vergés, J, and the PARSIFAL Team (N Zitellini, M Rovere, D Accetella, A Ribeiro, J Cabral, L Matias, R Bartolomé, M Farrán, D Casas, A Maldonado, A Pazos, D Córdoba, and X Roset) (2003) Mapping active faults offshore Portugal ( $\left.36^{\circ} \mathrm{N}-38^{\circ} \mathrm{N}\right)$ : Implications for seismic hazard assessment along the southwest Iberian margin. Geology 31:83-86 Henriques MC, Mouzinho MT, Ferrão NM (1988) Sismicidade de Portugal. O Sismo de 26 de Janeiro de 1531. Comissão para o Catálogo Sísmico Nacional, Lisboa 
IGeoE - Instituto Geográfico do Exército (2005) Carta Militar de Portugal Série M888, Folha 364

- Cartaxo, ISBN:972-765-264-6

Jambu N (1954) Application of composite slip surface for stability analysis. European Conference on Stability of Earth Slopes, Stockholm, Sweden

Justo JL, Salwa C (1998) The 1531 Lisbon earthquake. Bull Seismol Soc Am 88:319-328

Martins AA, Barbosa B (1992) Planaltos do Nordeste da Bacia Terciária do Tejo (Portugal).

Comun Serv Geol Portugal, 78(1):13-22

Martins AA (1999) Caracterização morfotectónica e morfosedimentar da Bacia do Baixo Tejo (Pliocénico e Quaternário). PhD Dissertation, Universidade de Évora

Martins AA, Cunha PP, Huot S, Murray AS, Buylaert JP (2009) Geomorphological correlation of the tectonically displaced Tejo River terraces (Gavião-Chamusca area, central Portugal) supported by luminescence dating. Quaternary International 199:75-91

Martins I, Mendes-Víctor LA (2001) Contribuição para o estudo da sismicidade de Portugal Continental. Instituto Geofísico do Infante D. Luís, Publ. 25, Universidade de Lisboa McCalpin JP, Carver, GA (2009) Paleoseismology of compressional tectonic environments. In: McCalpin JP (ed) Paleoseismology 2nd edn. Academic Press, Burlington, pp. 315-419 Mendonça JL, Cabral J (2003) Identificação de falhas na Bacia Cenozóica do Tejo através de técnicas de investigação hidrogeológica. Comun Inst Geol e Mineiro 90:91-102

Mezcua J (1982) Catalogo General de Isossistas de la Peninsula Iberica. Publicación 202, Instituto Geografico Nacional, Madrid

Moreira VS (1984) Sismicidade histórica de Portugal Continental. Revista do Instituto Nacional Meteorologia e Geofísica 3:3-79

Moreira, VS (1985) Seismotectonics of Portugal and its adjacent area in the Atlantic.

Tectonophysics 117:85-96

Moreira, VS (1991) Historical seismicity and seismotectonics of the area situated between the Iberian Peninsula, Morocco, Selvagens and Azores Islands. In: Mezcua J and Udías A (eds) Seismicity, Seismotectonics and Sismic Risk of the Ibero-Maghrebian Region, Publicacion I.G.N. Série Monografia n. 8, Instituto Geografico Nacional, Madrid, pp 213-225

Morgenstern NR and Price VE (1965) The analysis of the stability of general slip surfaces. Geotechnique 15:79-93

Oliveira CS (1986) A Sismicidade Histórica e a Revisão do Catálogo Sísmico. Proc. 36/11/7368, I e D, Estruturas, Relatório 99/86 - NDA, LNEC, Lisboa

Oliveira, CS, Sousa, ML (1991) A contribution to reduce subjectivity in treatment of historical data. In: Mezcua J and Udías A (eds) Seismicity, Seismotectonics and Sismic Risk of the IberoMaghrebian Region, Publicacion I.G.N. Série Monografia n. 8, Instituto Geografico Nacional, Madrid, pp. 97-114

Oliveira JT, Pereira E, Ramalho M, Antunes MT, Monteiro JH (coord.) (1992) Carta Geológica de Portugal, Escala 1:500.000, Instituto Geológico e Mineiro, Lisboa

Oliveira R (1973) An example of the influence of lithology on slope stability. Geotecnia 6:7-17 Peláez, JAM, Casado, CL, Romero, JH (2002) Deaggregation in magnitude, distance, and azimuth in the South and West of the Iberia Peninsula. Bull Seismol Soc Am 92:2177-2185 
Ramos C, Reis E, Pereira AR, Azevêdo TM, Nunes E, Freitas, MC and Andrade C (2002) Late

Holocene evolution of the Lower Tagus alluvial plain and heavy metals content: preliminary results. In: JM Garcia-Ruiz, JAA Jones and J Armáez (eds.), Environmental Change and Water Sustainability, Study Group on Water Sustainability of the Int. Geog. Unit, Zaragoza, 167-182 Rasmussen ES, Lomholt S, Andersen C, Vejbæk OV (1998) Aspects of the structural evolution of the Lusitanian Basin in Portugal and the shelf and slope area offshore Portugal. Tectonophysics 300:199-225

Ribeiro A, Cabral J, Batista R, Matias LM (1996) Tectonic stress pattern in Portugal mainland and the adjacent Atlantic region (West Iberia). Tectonics 15:641-659

Simão NMM (2003) Aplicações de Sísmica de Reflexão e Refracção na Geotecnia. Graduation Dissertation, Universidade de Lisboa Sousa ML, Martins A, Oliveira CS (1992). Compilação de catálogos sísmicos da região ibérica. Proc. 36/11/9295, Laboratório Nacional de Engenharia Civil, Lisboa

Terrinha, P, Pinheiro, LM, Henriet, J-P, Matias, L, Ivanov, MK, Monteiro, JH, Akhmetzhanov, A, Volkonskaya, A, Cunha, T, Shaskin, P, Rovere, M, and the Ttr10 Shipboard Scientific Party (2003) Tsunamigenic-seismogenic structures. Neotectonics, sedimentary processes and slope instability on the southwest Portuguese margin. Marine Geology 195:55-73 Teves-Costa P, Rio I, Marreiros C, Ribeiro R, Borges JF (1999) Source parameters of old earthquakes: semi-automatic digitization of analog records and seismic moment assessment. Natural Hazards 19:205-220

Stich D, J. Batlló, Macià R, Teves-Costa P, Morales J (2005) Moment tensor inversion with single-component historical seismograms: The 1909 Benavente (Portugal) and Lambesc (France) earthquakes. Geophys J Int 162:850-858

Vilanova SP (2003) Sismicidade e perigosidade sísmica do Vale Inferior do Tejo, Ph.D. Dissertation, Instituto Superior Técnico, Lisboa Vilanova, SP, Nunes, CF, Fonseca, JFBD (2003) Lisbon 1755: A Case of Triggered Onshore Rupture? Bull Seismol Soc Am 93, 2056-2068

Vilanova SP, Fonseca JFBD (2004) Seismic hazard impact of the Lower Tagus Valley Fault Zone (SW Iberia). J. Seismol. 8:331-345

Vis G-J, Kasse C, Vanderberghe J (2008) Late Pleistocene and Holocene palaeogeography of the Lower Tagus Valley (Portugal): effects of relative sea level, valley morphology and sediment supply. Quat Sci Rev 27:1682-1709. doi: 10.1016/j.quascirev.2008.07.003 Vis G-J (2009) Fluvial and marine sedimentation at a passive continental margin. The late Quaternary Tagus depositional system. PhD. Dissertation, VU University Amsterdam Zitellini, N, Chierici F, Sartori, R, Torelli, L (1999) The tectonic source of the 1755 Lisbon earthquake and tsunami. Annali di Geofisica 42:49-55

Zitellini, N, Mendes Victor, LA, Cordoba, D et al (2001) The 1755 Lisbon earthquake and Tsunami: localization and investigation of the tectonic source. EOS, Transactions, Am Geophys Union 82:290-1 
Zitellini, N, Rovere, M, Terrinha, P, Chierici, F, Matias, L, and BIGSETS Team (2004) Neogene Through Quaternary Tectonic Reactivation of SW Iberian Passive Margin, Pure and Apl Geophis $161: 567-587$

Fig 1 Geographic setting of the study region (framed area). Portuguese mainland relief from $200 \mathrm{~m}$ grid digital terrain model; VCO, Vila Chã de Ourique

Fig 2 Geological setting of the VCO site, adapted from (Oliveira et al. 1992). 1, Paleozoic basement; 2 and 3, Jurassic and Cretaceous sediments of the Lusitanian Basin, respectively; 4, Sintra Late-Cretaceous intrusive massif; 5, 6 and 7, Paleogene, Miocene and Pliocene sediments of the Lower Tagus Basin, respectively; 8 and 9, Pleistocene and Holocene fluvial sediments of the Tagus river, respectively; 10, mapped fault; 11, mapped reverse fault; AB, Algarve Basin; LB, Lusitanian Basin; LTB, Lower Tagus Basin; star, VCO site

Fig 3 a and b, seismic intensities (I MM) for the 1531 and 1909 earthquakes in the Lower Tagus Valley, respectively; isoseismal lines for the 1531 event (a) adapted from Oliveira (1986), isoseismal lines for the 1909 event (b) adapted from Moreira (1984). c, epicentre distribution of instrumental seismicity in the Lower Tagus Valley Region and adjacent areas for the period 1960 2007, with $M \geq 2$ (264 events) (compilation from Martins and Mendes-Victor 2001, Sousa et al. 1992, Carrilho et al. 2004 and the online information from the Instituto de Meteorologia http://www.meteo.pt)

Fig 4 Digital terrain model of part of the Lower Tagus Valley including the Vila Chã de Ourique site (VCO). Shaded relief, minimum and maximum heights of $1 \mathrm{~m}$ and $211 \mathrm{~m}$ respectively, no vertical exaggeration; Az, Azambuja, SA, Santarém

Fig 5 North-westward view of the slope at the right bank of the Tagus River valley immediately north of the VCO site, taken from the recent alluvial plain

Fig 6 Longitudinal profiles of two tributaries of the Tagus River located near VCO, and valley cross-sections. a, location map, adapted from 1:25,000 scale topographic map, with 10m contour interval (IGeoE 2005). b, river and valley profiles, vertical exaggeration, $5 \times$, dashed, eastern tributary of river 1 , dashed and dotted, western tributary of river 1

Fig 7 Topography of VCO site, obtained by field topographic survey, with location of the trenches and the mechanical and hand-auger holes; stereographic projection of slip surfaces and striae measured in the trenches 
Fig 8 a, simplified log of the borehole drilled at VCO, depth of observed slip surfaces represented in the right-hand column; b, example of a striated slip surface in the borehole core, slip direction indicated by arrow

Fig 9 New outcrop near the railway underground passage, VCO site. a, general view, Col 1 - Col 3, older to younger colluvium, M1, Miocene whitish sands, M2, Miocene clayey silts, Ps, paleosol, $\mathrm{S}$, striated slip surface $\left(070^{\circ}, 65^{\circ} \mathrm{SE}\right),\left(050^{\circ}, 60^{\circ} \mathrm{SE}\right)$; b, detail of the outcrop, dashed lines indicate the trace of slip surfaces

Fig 10 Schematic cross section at the VCO site showing the interpreted gravitational slide surfaces

Fig 11 Schematic evolution of the proposed model (top to bottom); borehole II data from Fonseca et al, personal communication

Fig 12 Summary of results of direct shear tests (peak and residual) of clay samples collected in the trenches and borehole, in near drained conditions (shear velocity $0.01 \mathrm{~mm} / \mathrm{min}$ )

Fig 14 Location map of the four high-resolution seismic reflection profiles (VCO1-4) that were first acquired at the VCO site; Tch, trenches; contour lines every $10 \mathrm{~m}$, first line at $10 \mathrm{~m}$

Fig 15 Seismic reflection profile VCO4; B.Al., base of Holocene alluvium, I.M., intra-Miocene horizon

Fig16 a, Google Earth satellite image showing the VCO site, with the locations of the trenching site, the new outcrops and the newly acquired seismic line (A-B) indicated; black dashed line average trend of the steep slip surface exposed in the new outcrops; b, seismic reflection section $\mathrm{VCO}-\mathrm{AB}$

Table 1 Index properties of samples of the clays and silts unit (from 0.5 to $5.9 \mathrm{~m}$ depth in the borehole located on the slope, Figures 7 and 8)

\begin{tabular}{|l|c|c|c|c|c|c|c|c|c|c|}
\hline & $\begin{array}{c}\mathrm{CaCO}_{3} \\
(\%)\end{array}$ & $\begin{array}{c}\mathrm{Clay} \\
(\%)\end{array}$ & $\begin{array}{c}\text { Silt } \\
(\%)\end{array}$ & $\begin{array}{c}\text { Sand } \\
(\%)\end{array}$ & $\begin{array}{c}\text { Gravel } \\
(\%)\end{array}$ & $\begin{array}{c}\text { Liquid } \\
\text { limit } \\
(\%)\end{array}$ & $\begin{array}{c}\text { Plastic } \\
\text { limit } \\
(\%)\end{array}$ & $\begin{array}{c}\text { Shrinkage } \\
\text { limit } \\
(\%)\end{array}$ & $\begin{array}{c}\text { Plasticity } \\
\text { Index } \\
(\%)\end{array}$ & $\begin{array}{c}\text { Dry specific } \\
\text { weight } \\
\left(\mathrm{kN} / \mathrm{m}^{3}\right)\end{array}$ \\
\hline Slide clay 1 & 5.4 & 25.4 & 64.2 & 7.8 & 2.6 & 55 & 18 & 10 & 37 & 20.209 \\
\hline Top clay 2 & 6.8 & - & - & - & - & 53 & 21 & 11 & 32 & 19.816 \\
\hline Lower clay 3 & 7.9 & - & - & - & - & 57 & 23 & 10 & 34 & 18.149 \\
\hline
\end{tabular}


colour figure

Click here to download high resolution image

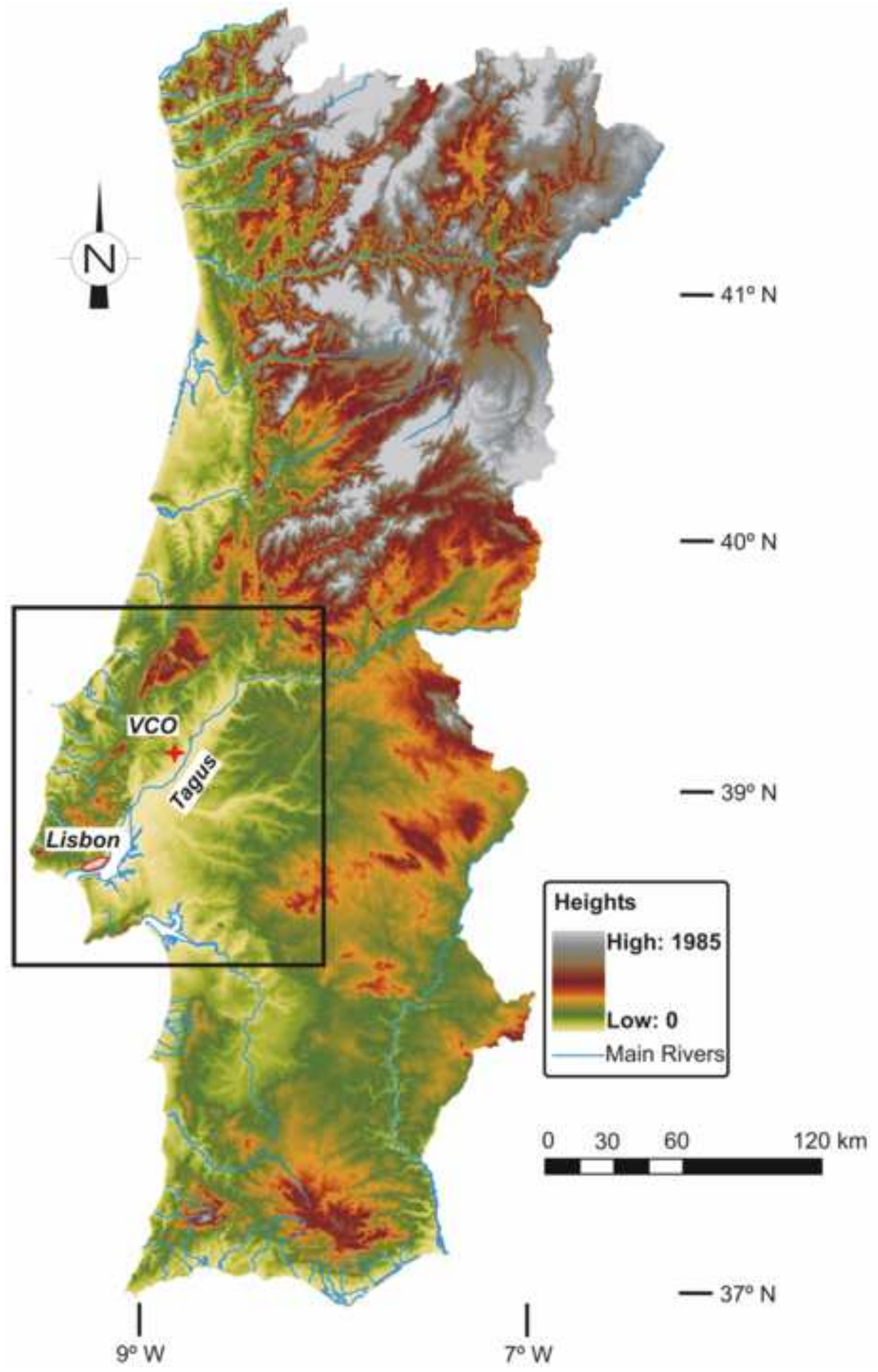




\section{colour figure}

Click here to download high resolution image

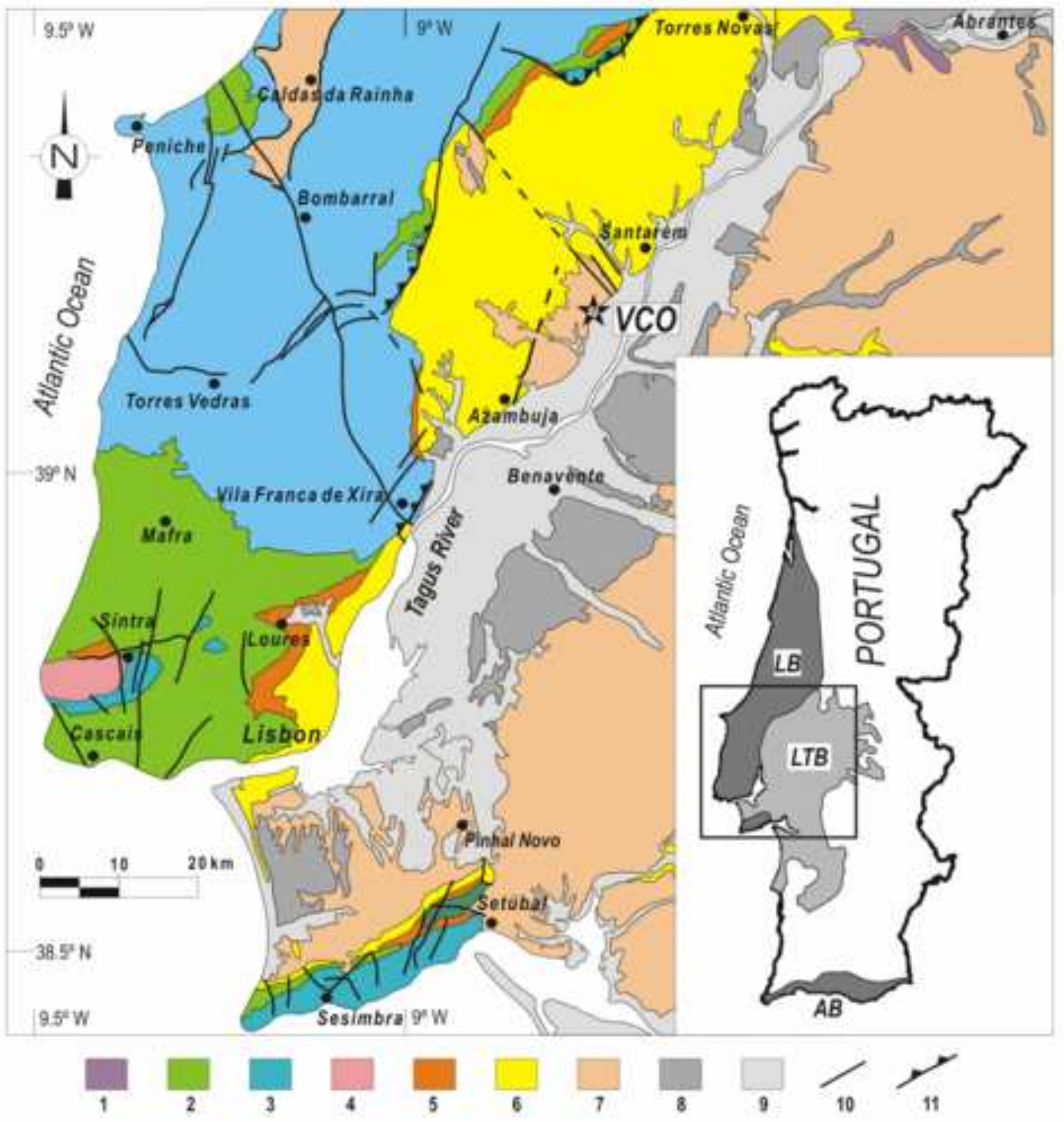


Click here to download high resolution image

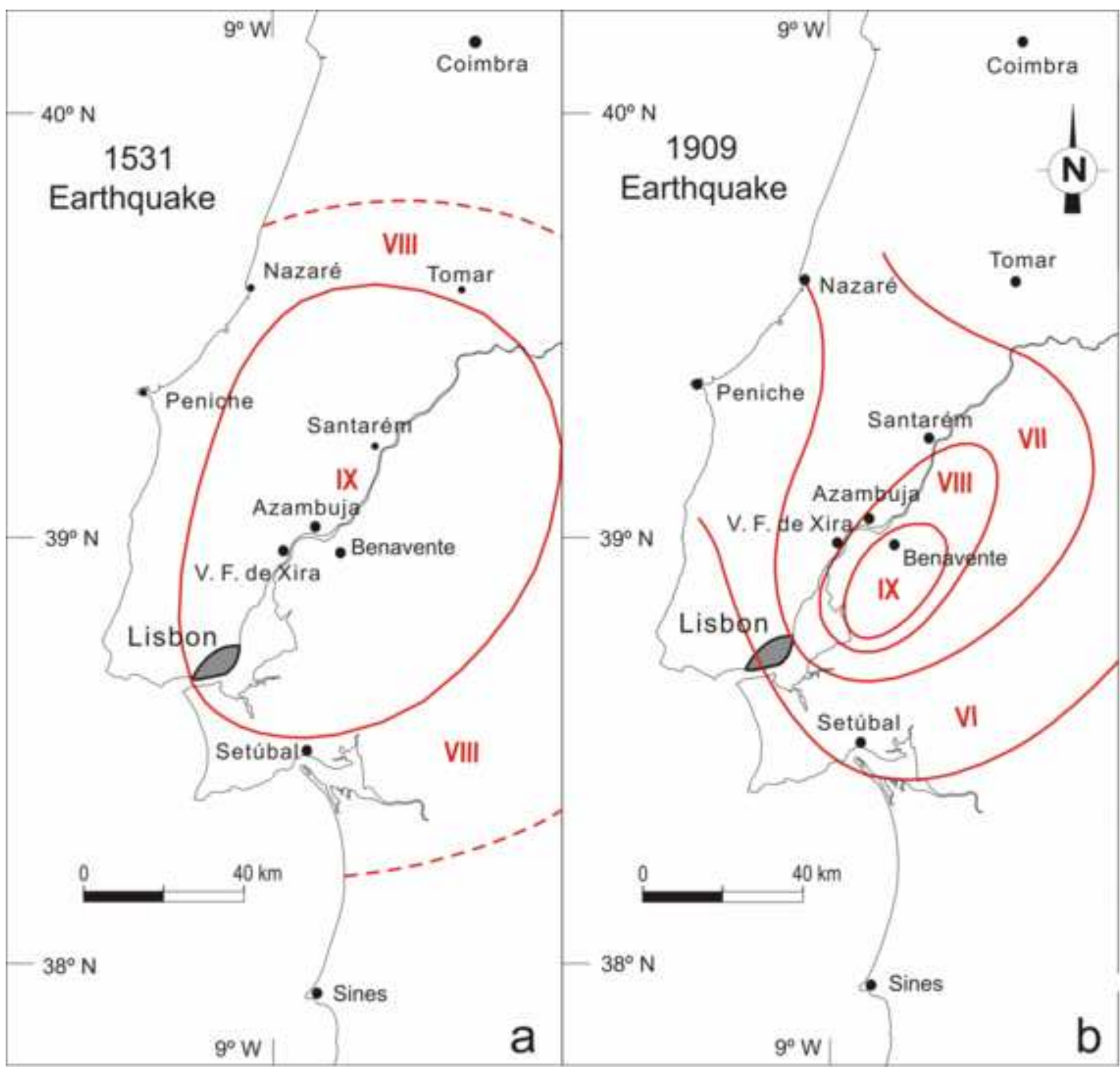




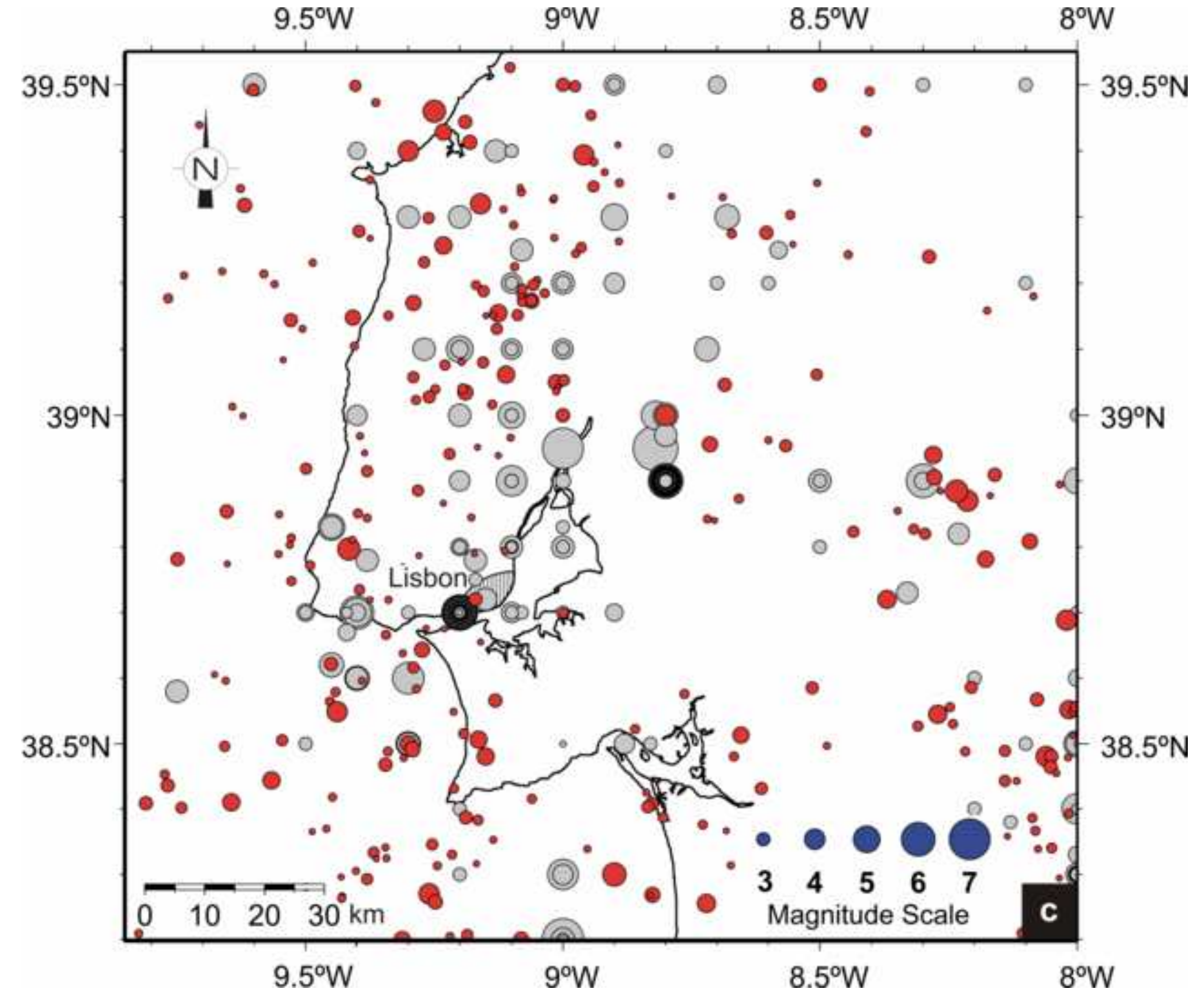

Click here to download high resolution image 
Click here to download high resolution image

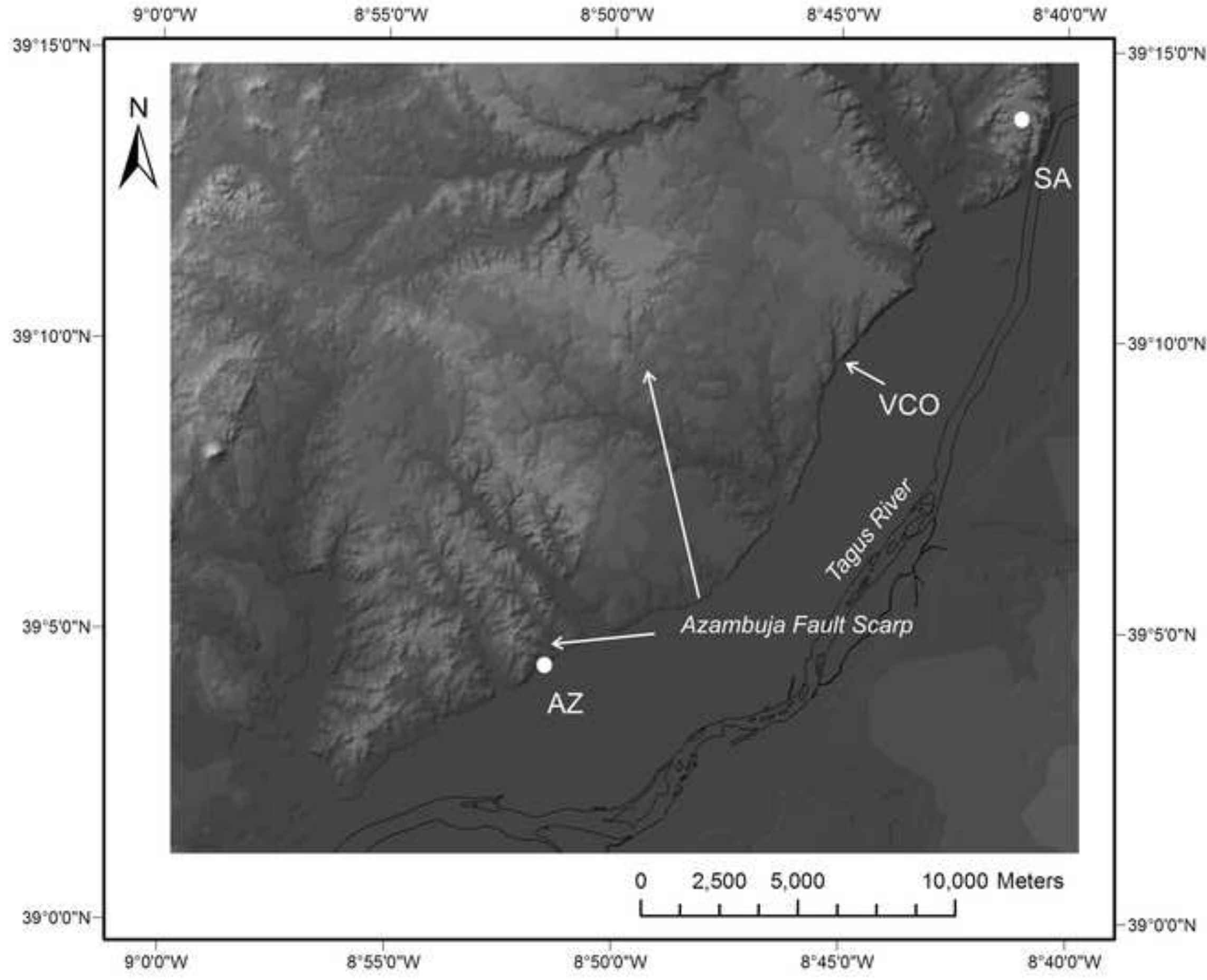




\section{SW}
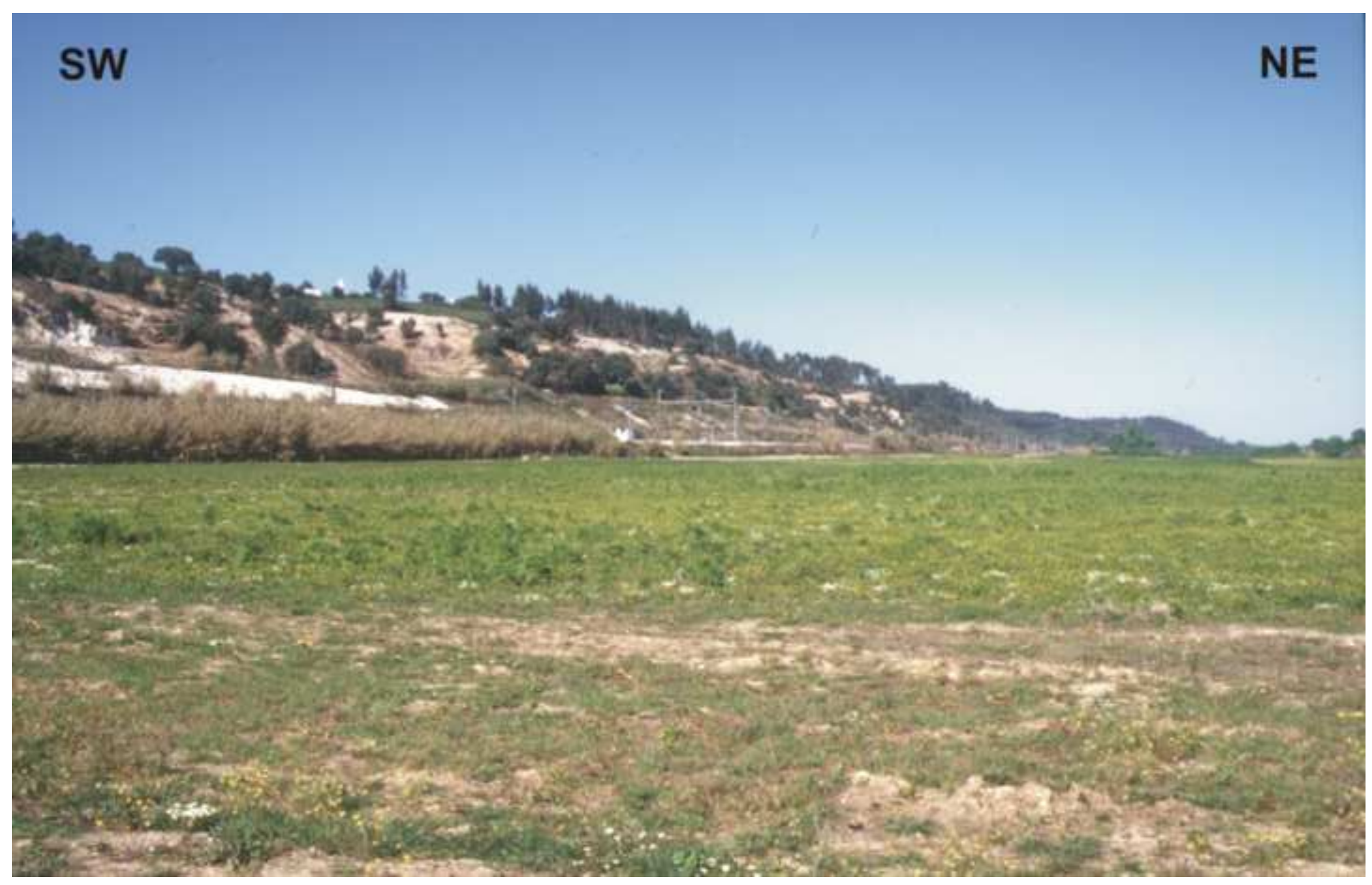


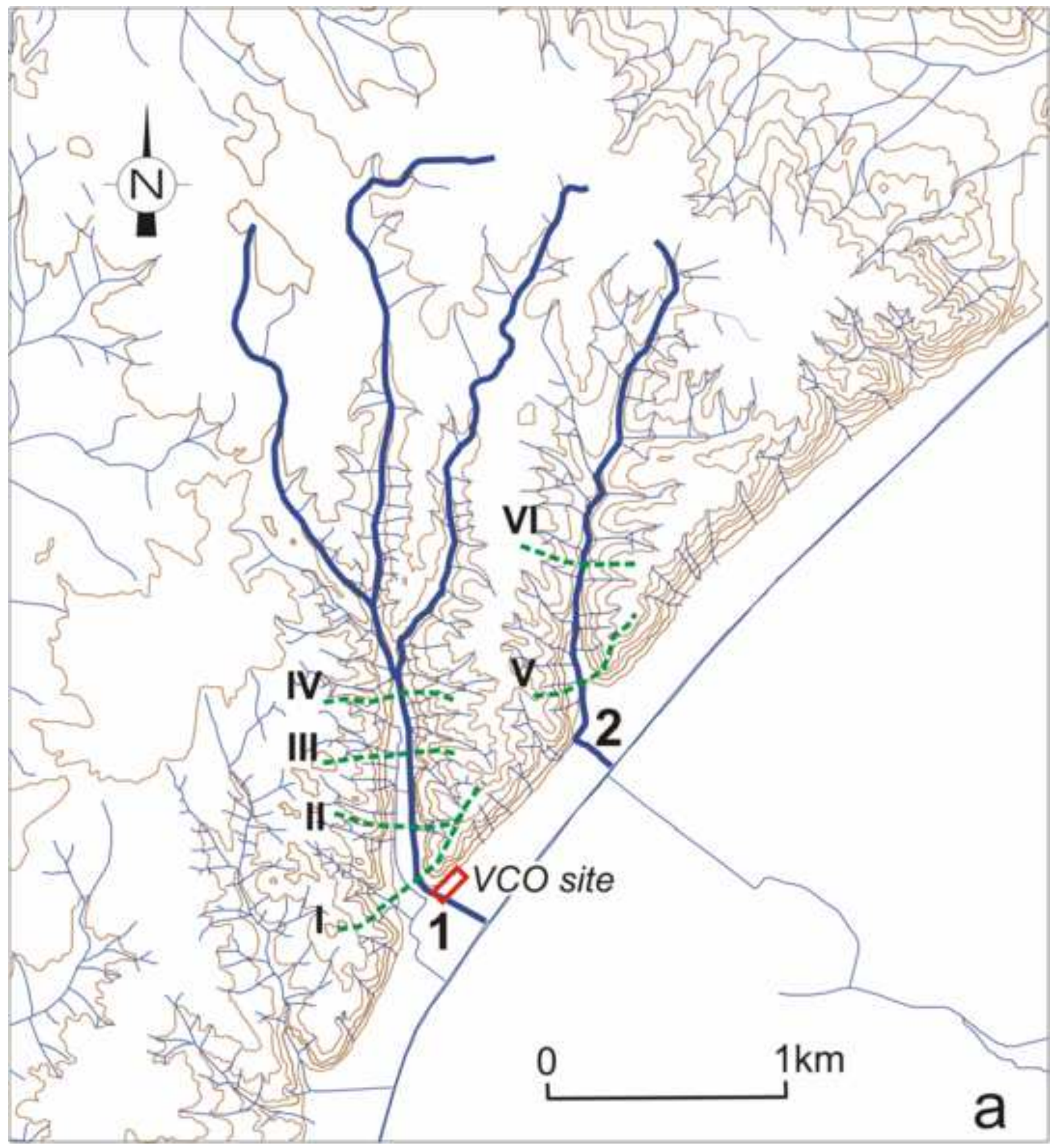


Click here to download high resolution image
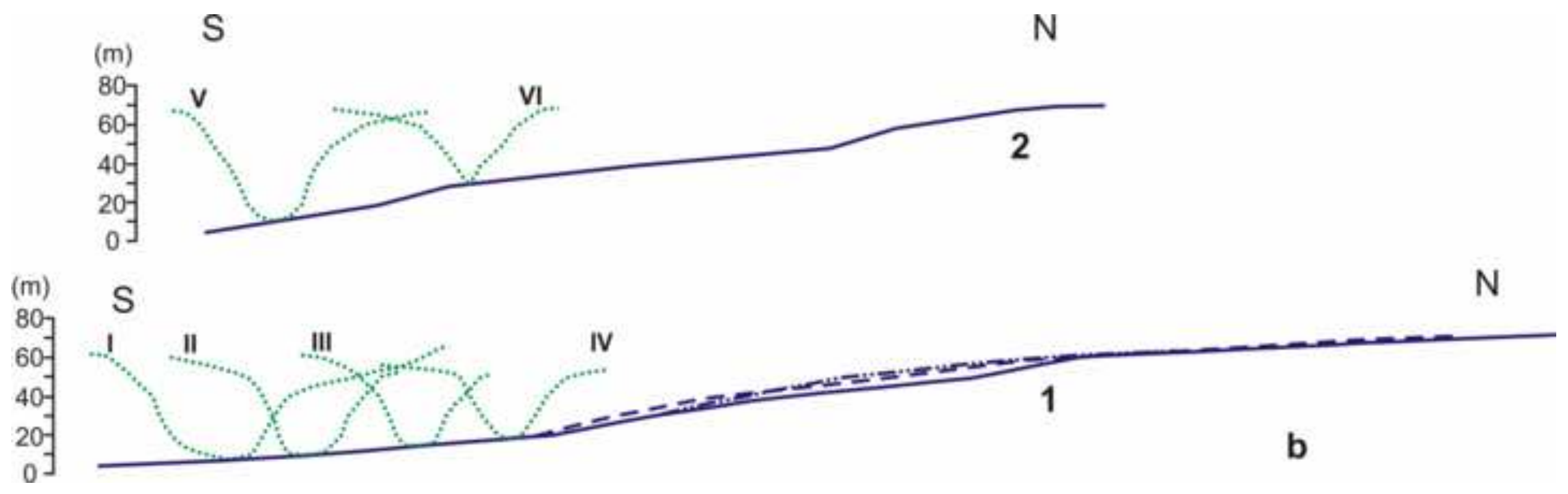


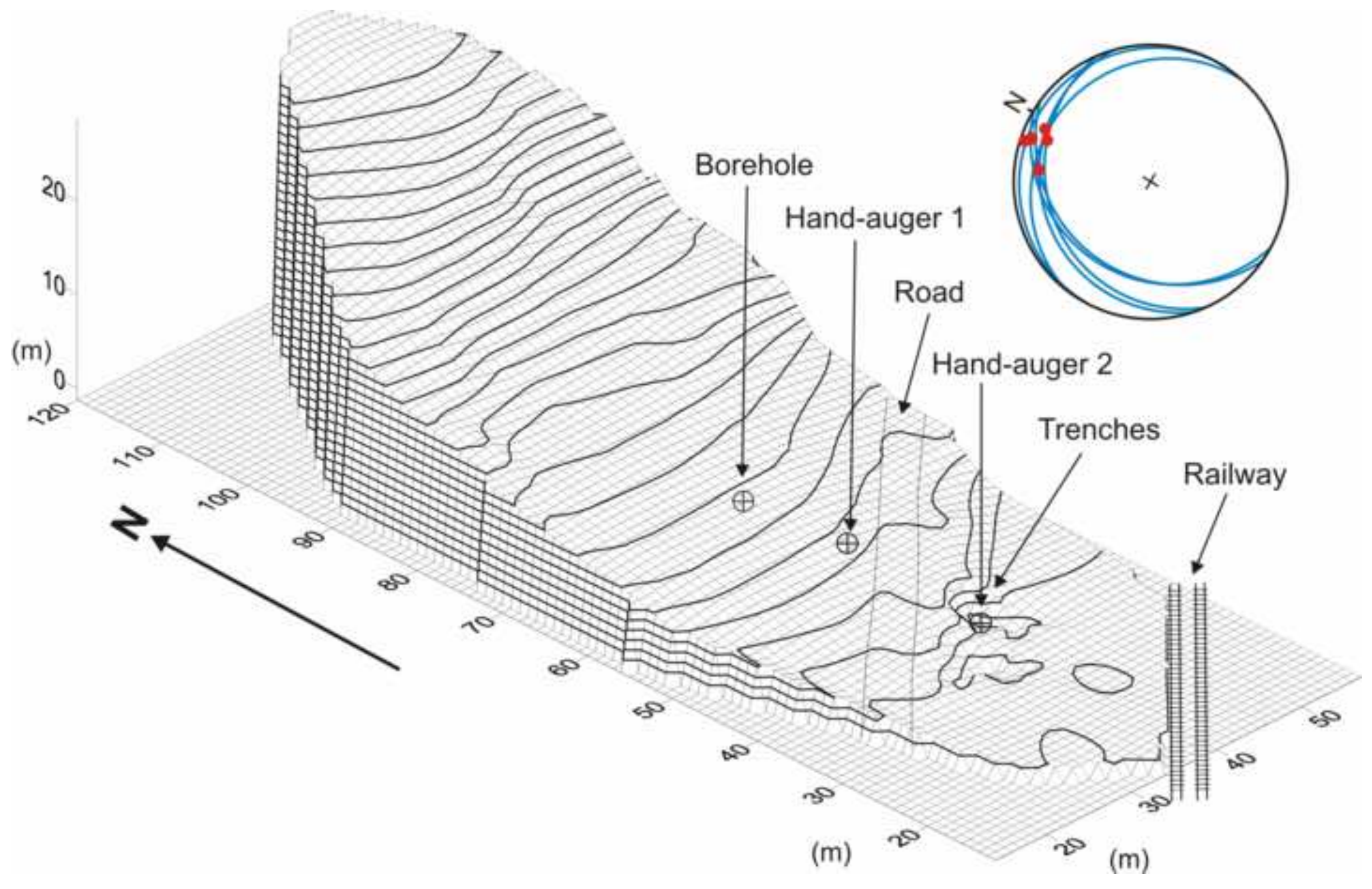




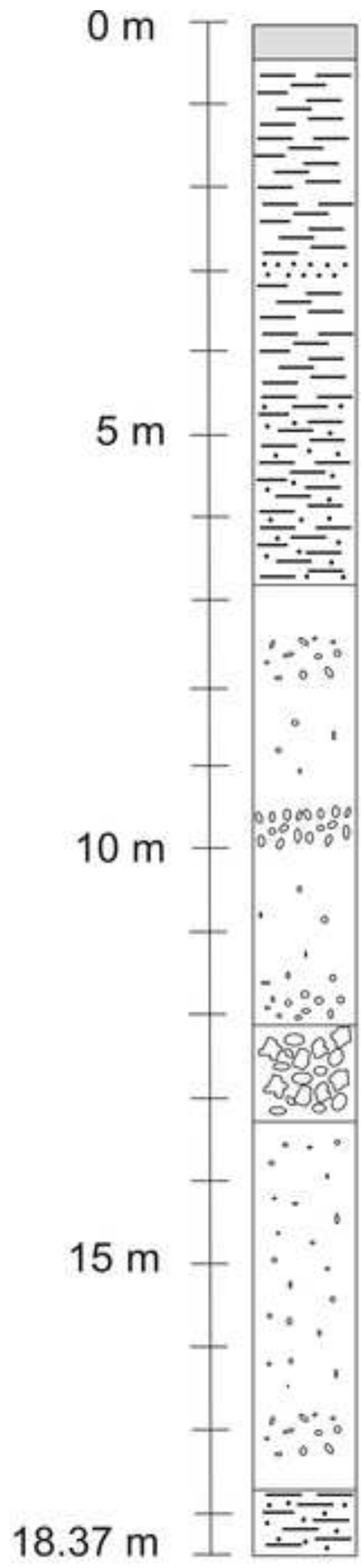

$\square$ Present soil

Light olive-gray plastic clays, with carbonate concretions

Pale olive and yellowish brown micaceous silt

White, light gray and yellowish-red fine sands with interbedded coarse sand to gravelly layers

Gravel with centimetric quartz and quartzite pebbles

White fine sands with silty clayey matrix and scattered coarse quartz grains

Pale olive and yellowish brown micaceous clays and silts 


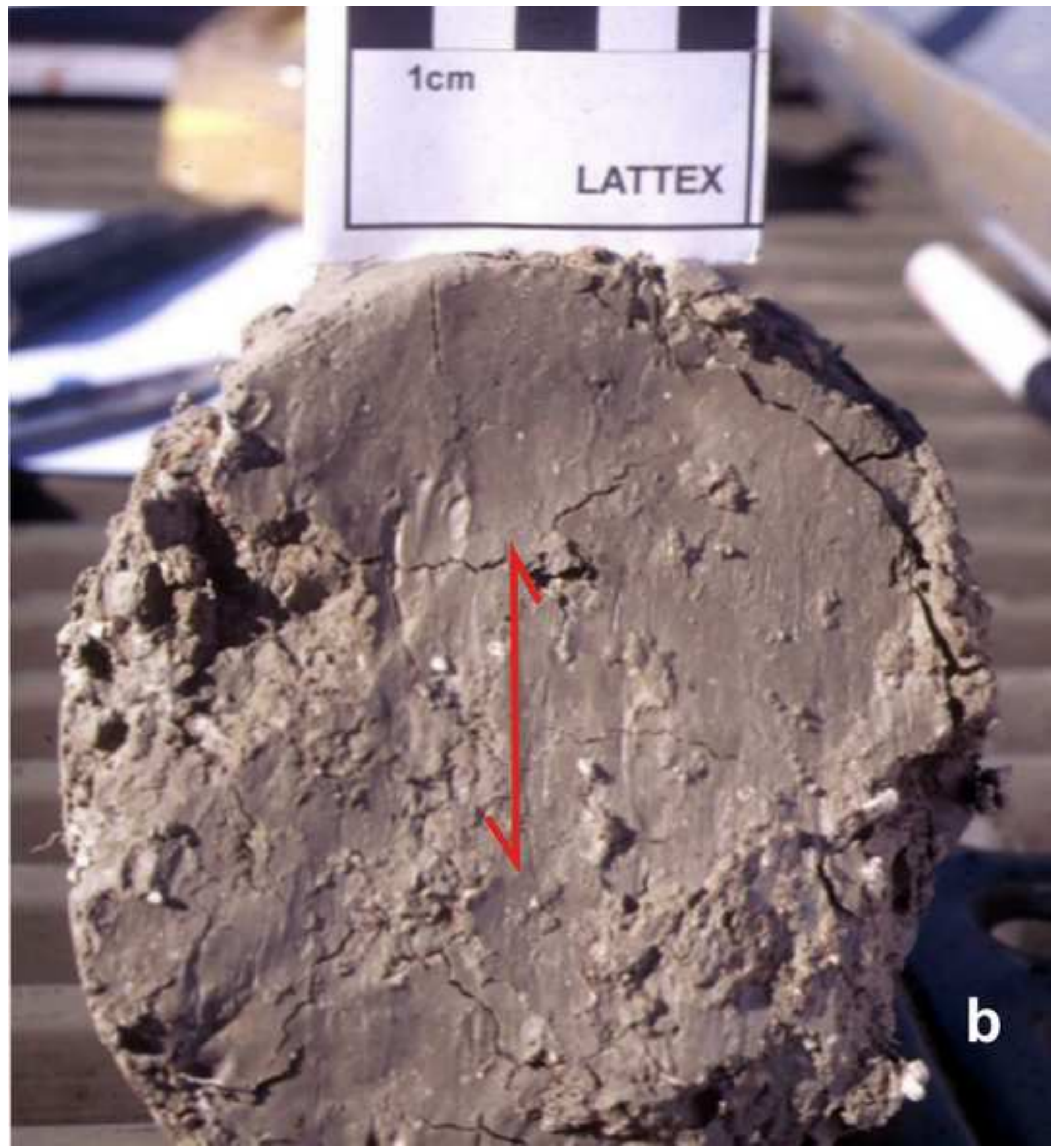




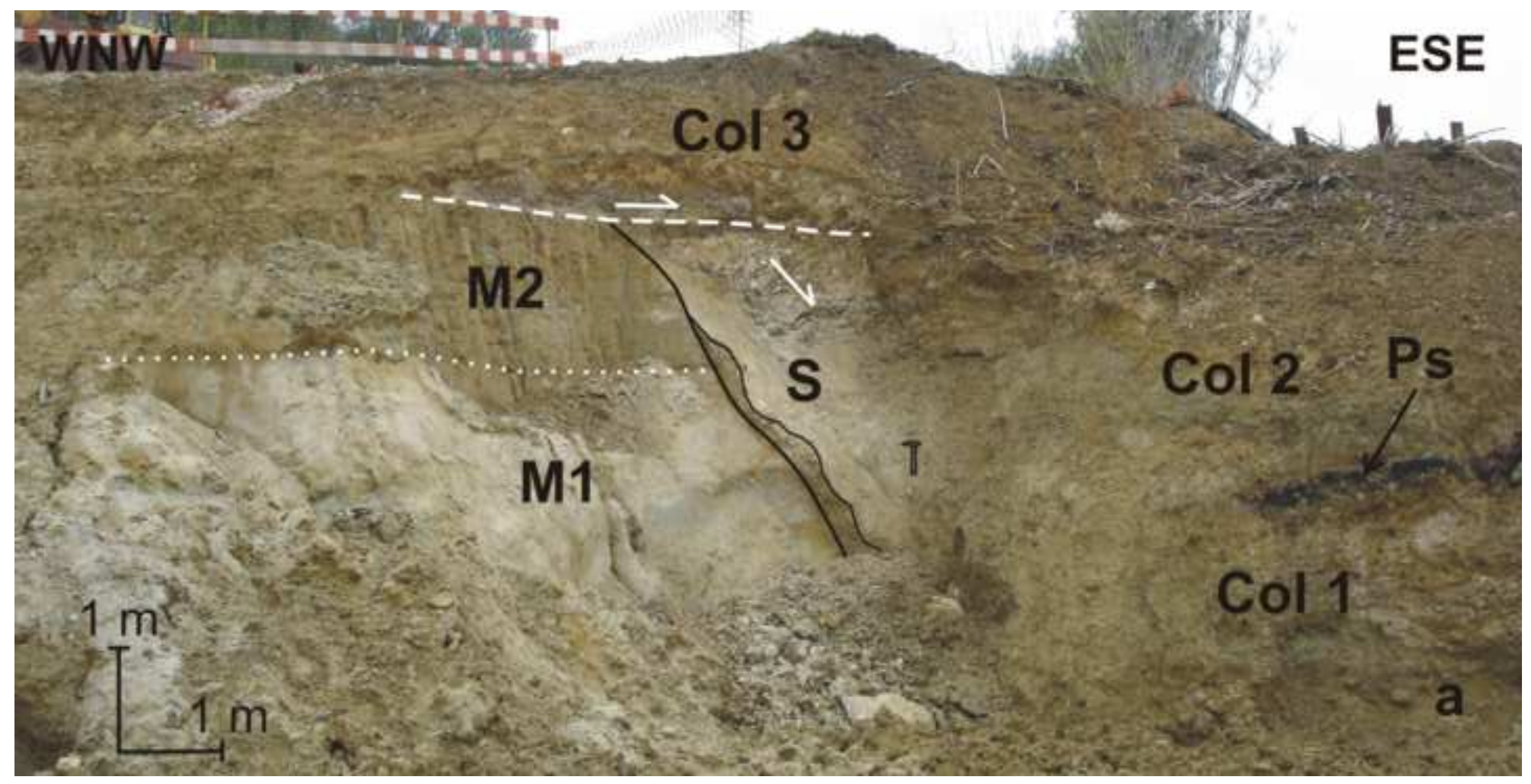


- NNW -

- SSE -

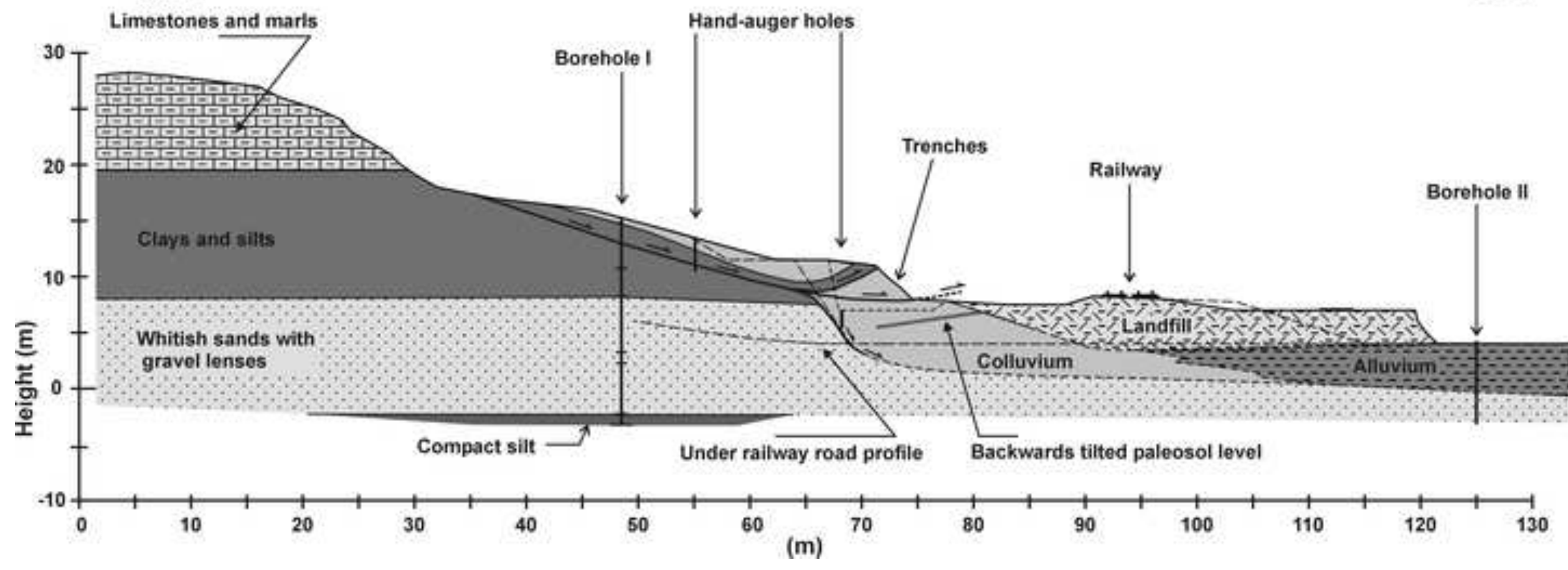




\section{colour figure}

Click here to download high resolution image
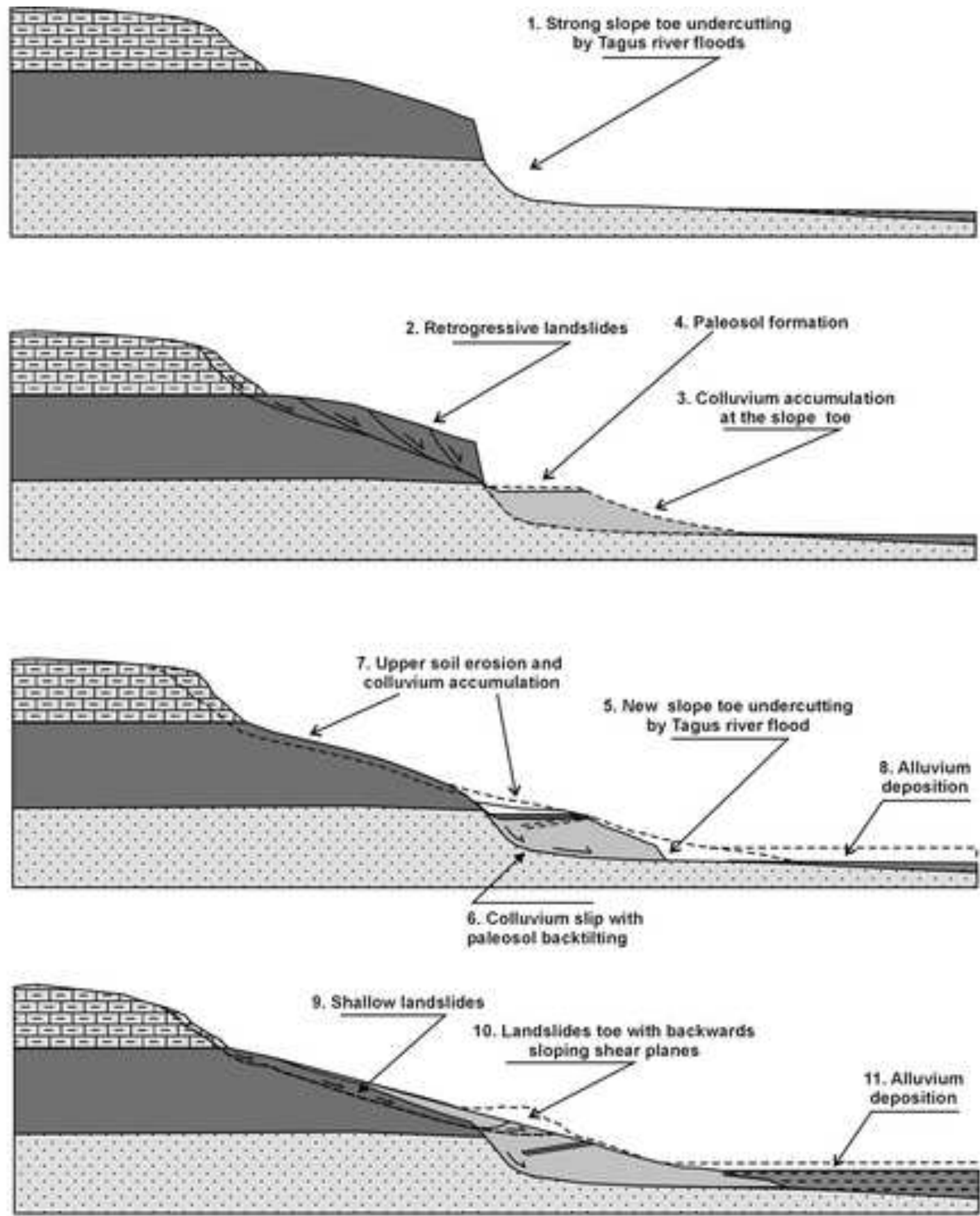

\section{- NNW -}

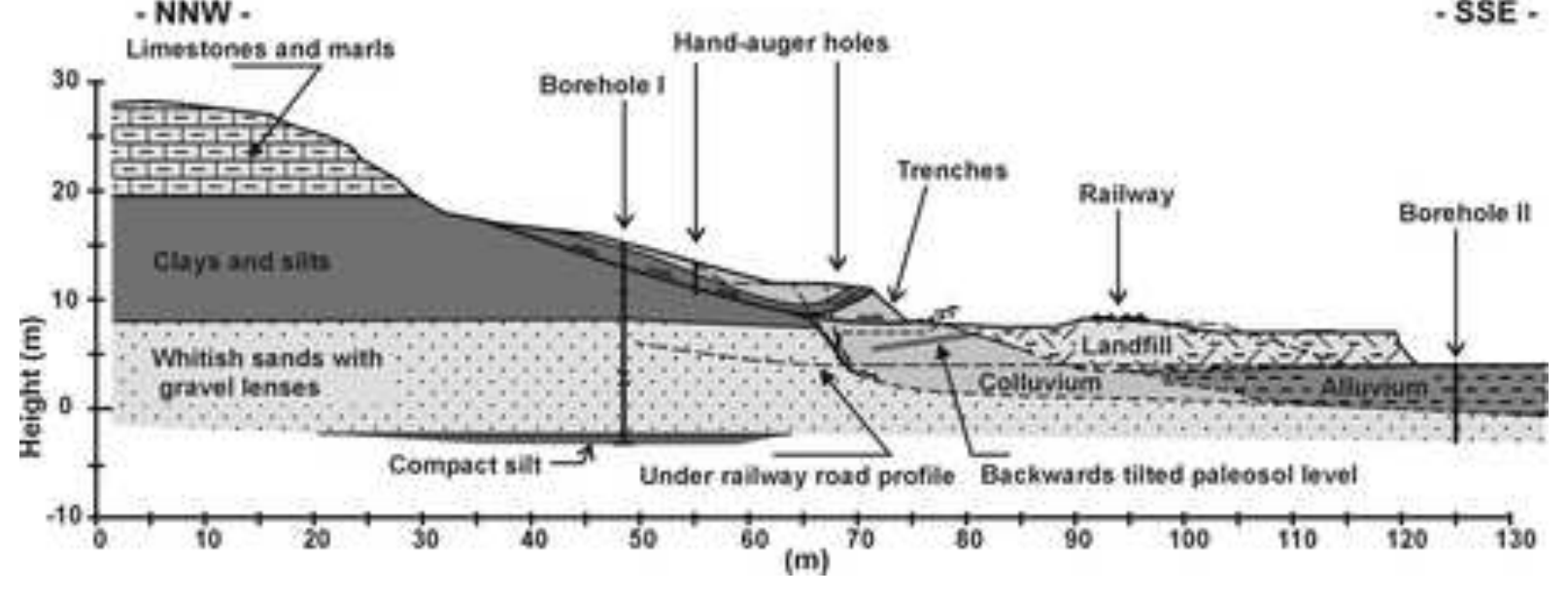




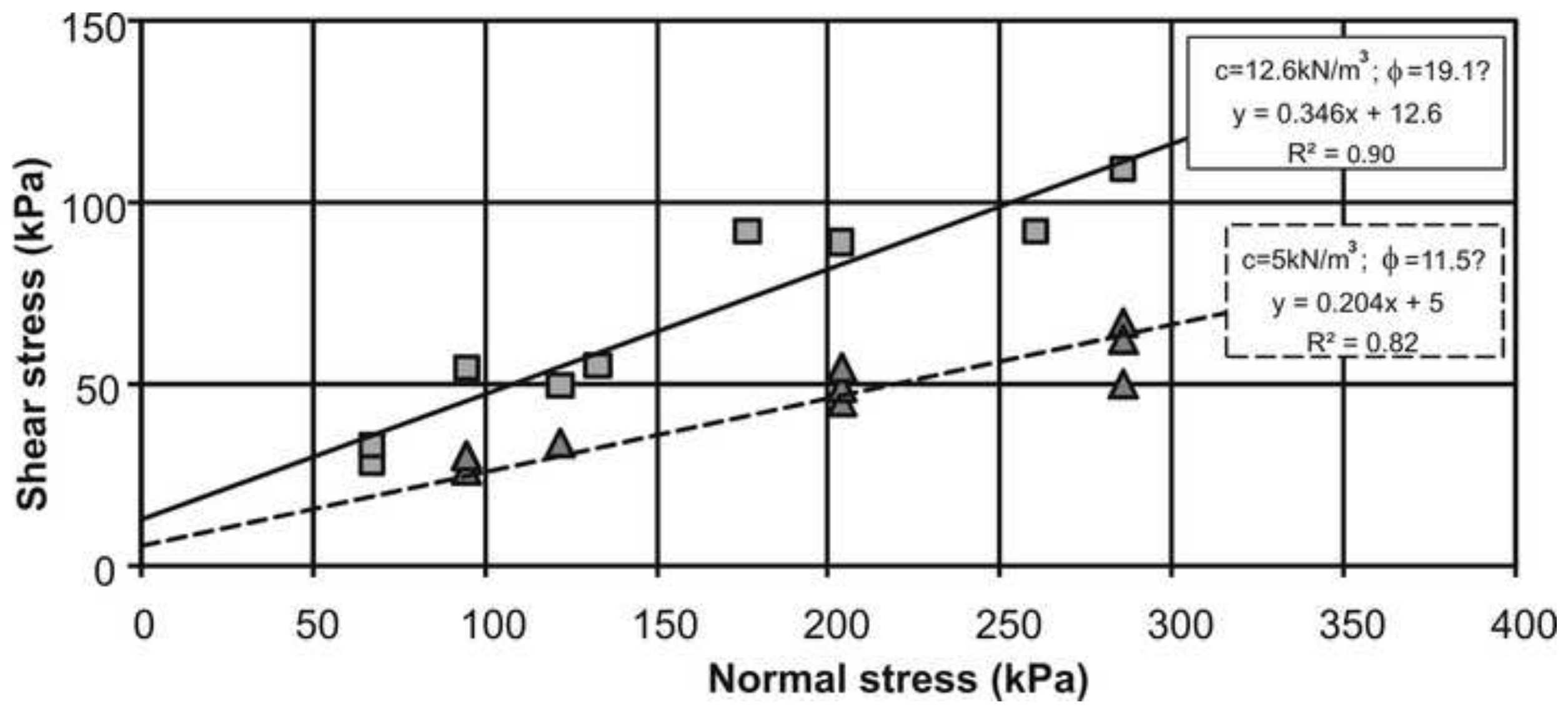



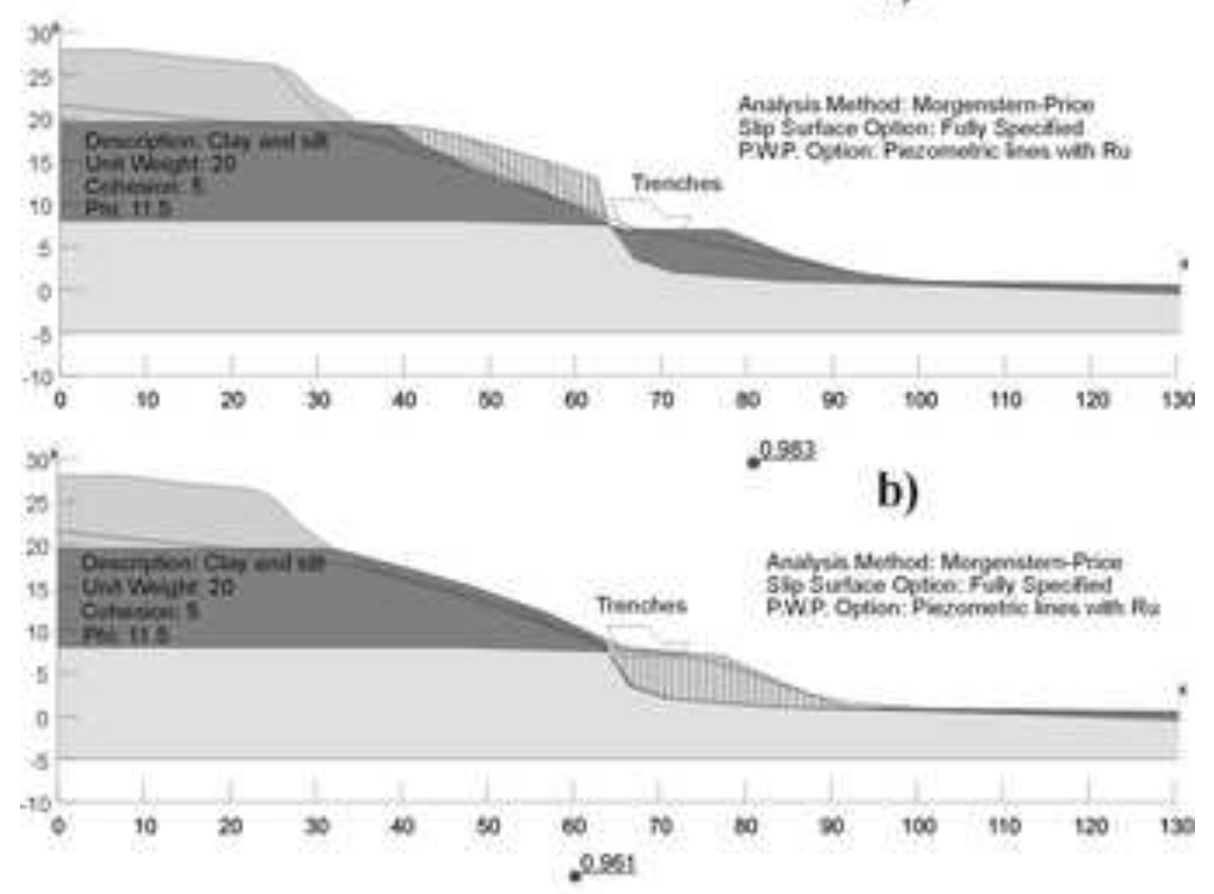

c)

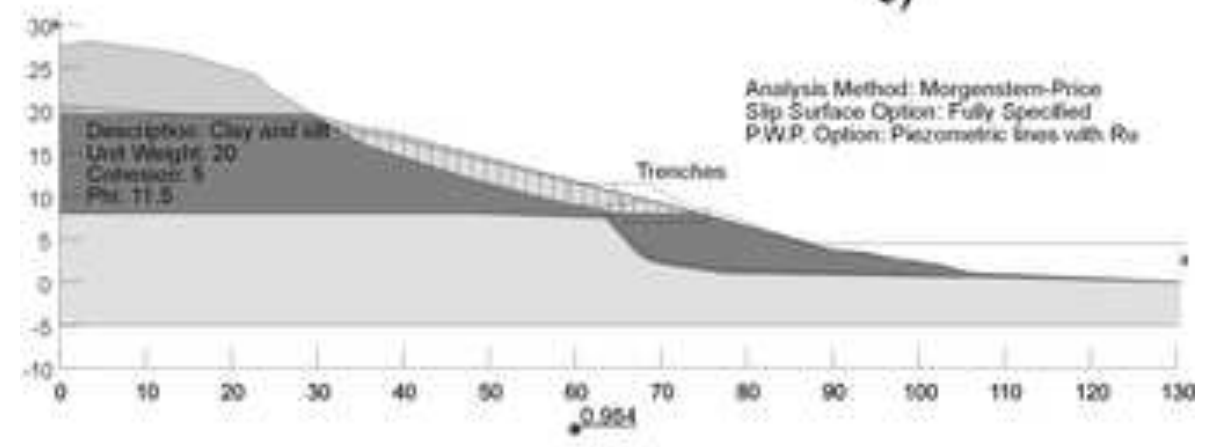

d)
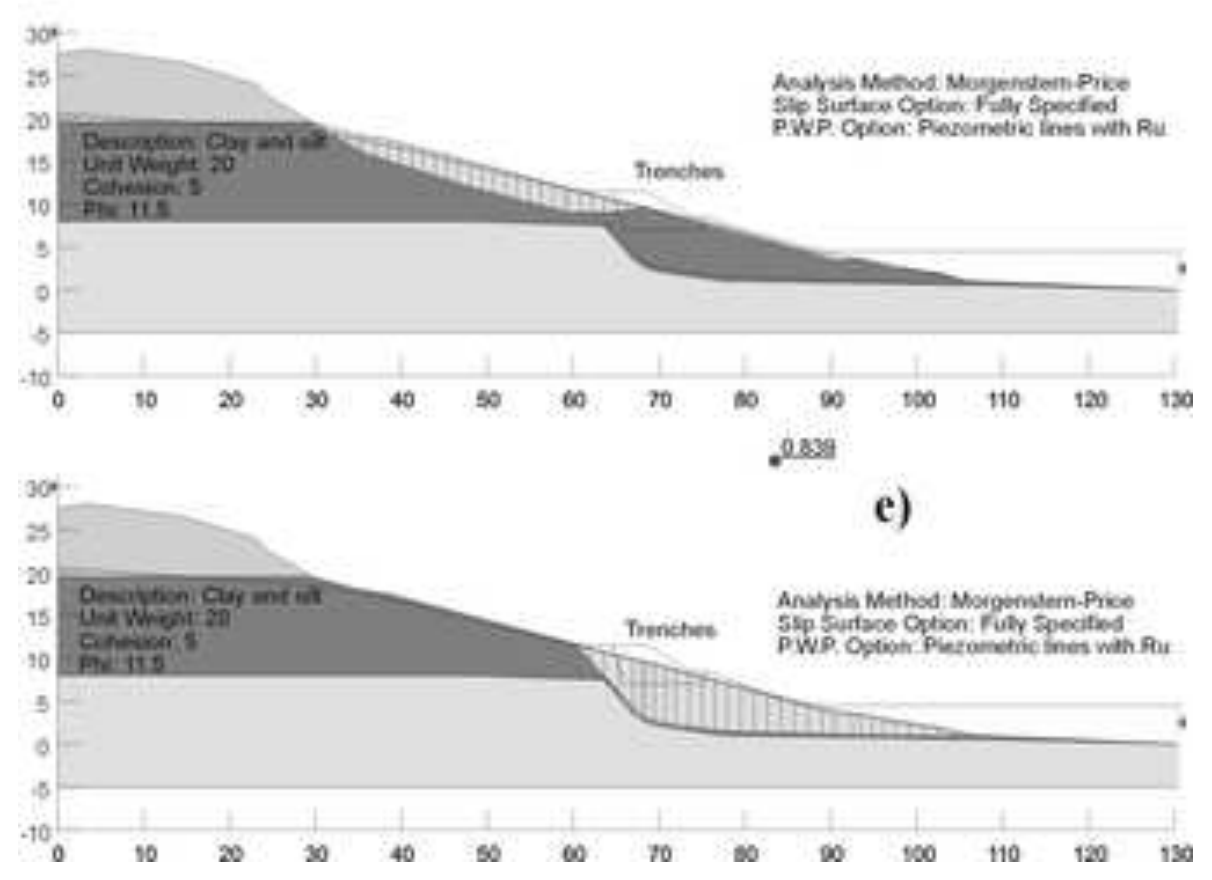
Click here to download high resolution image

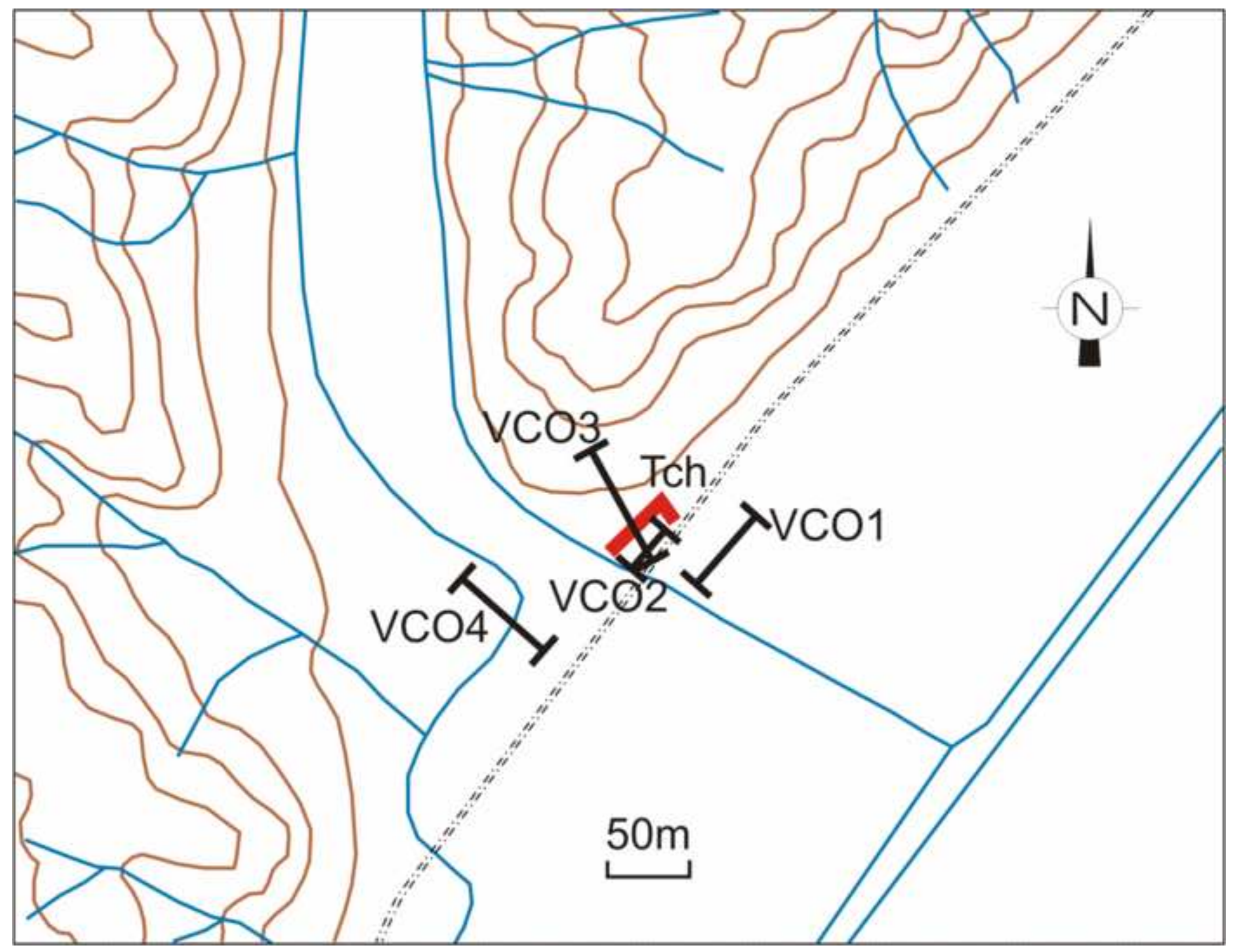




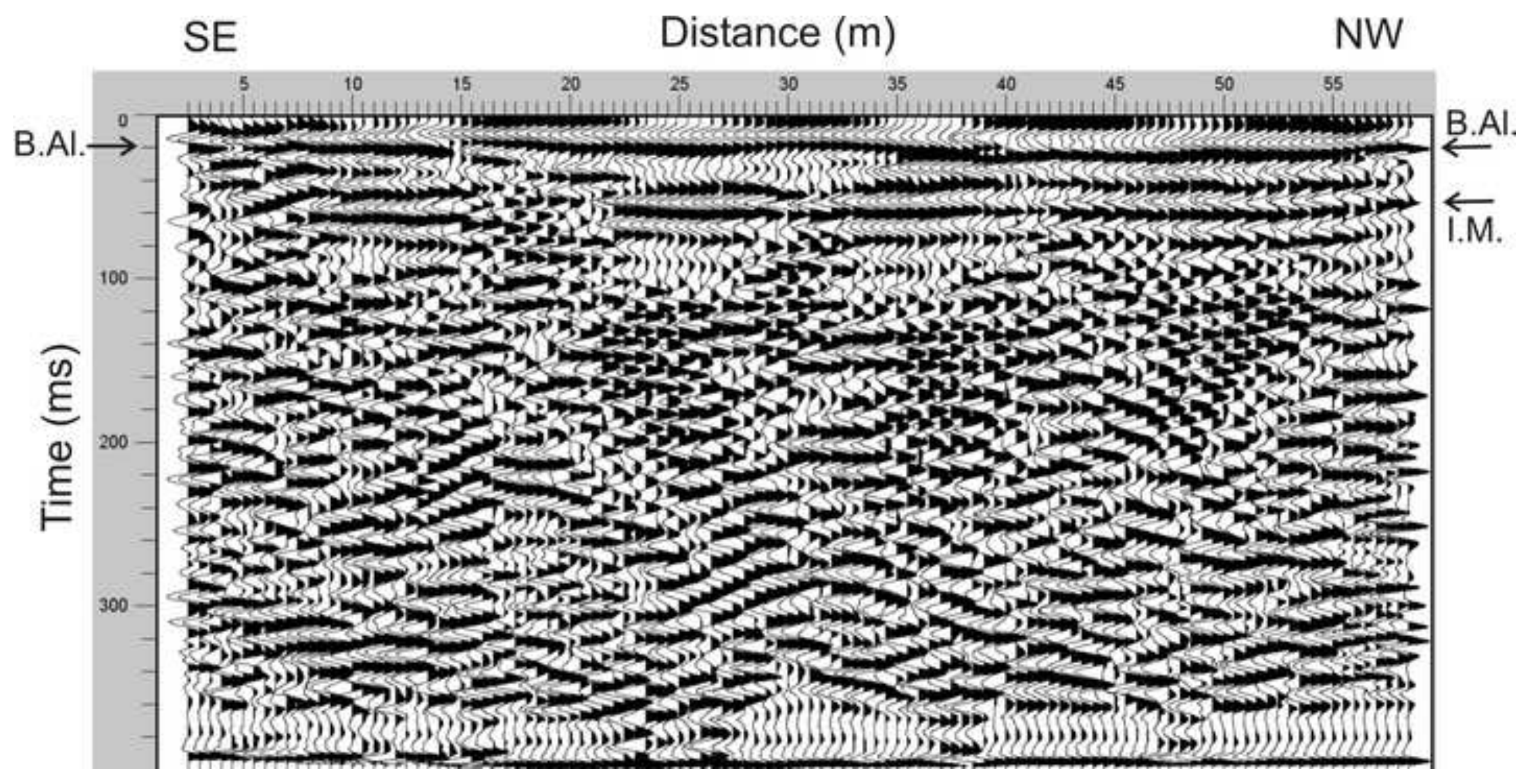




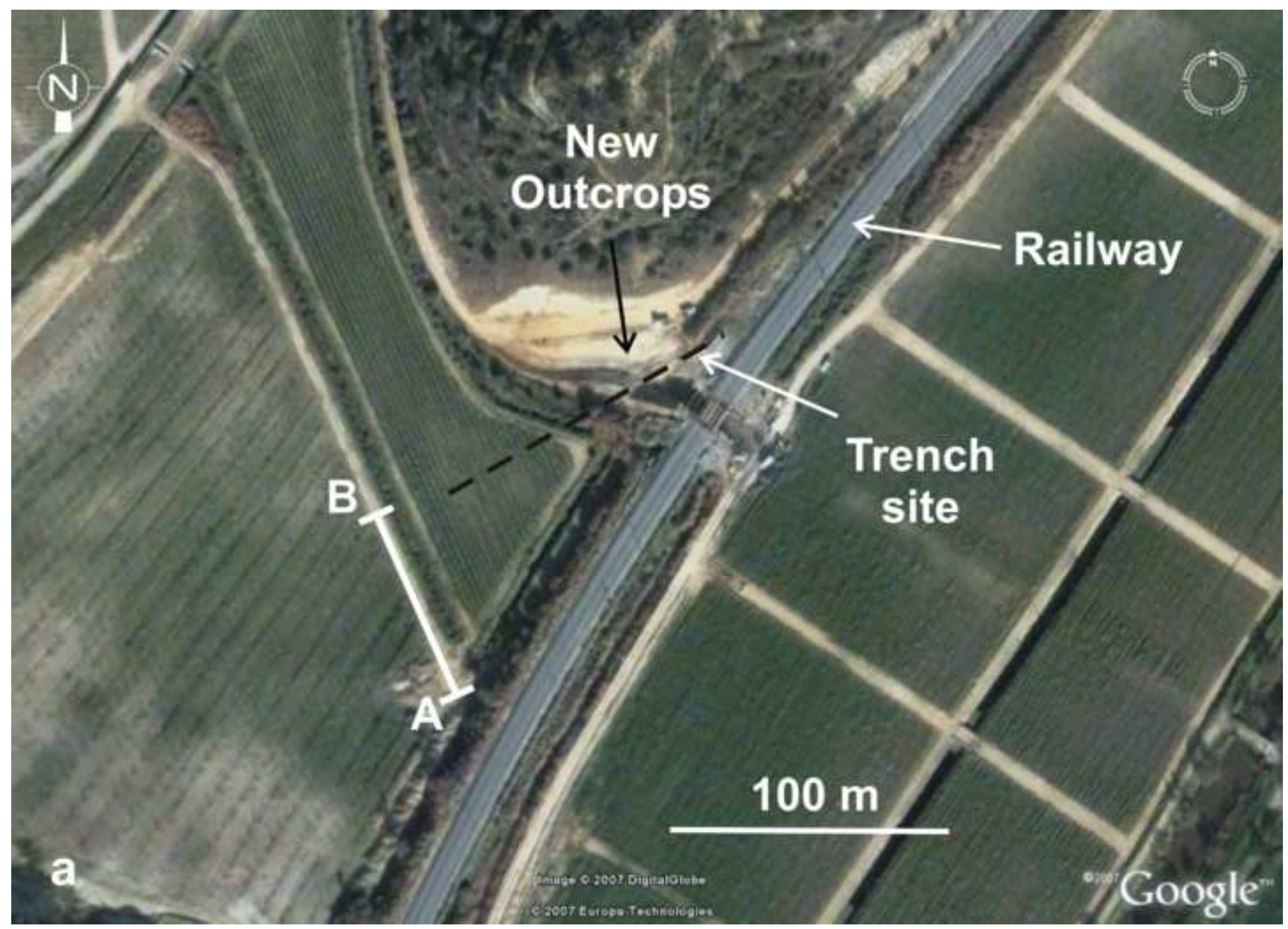




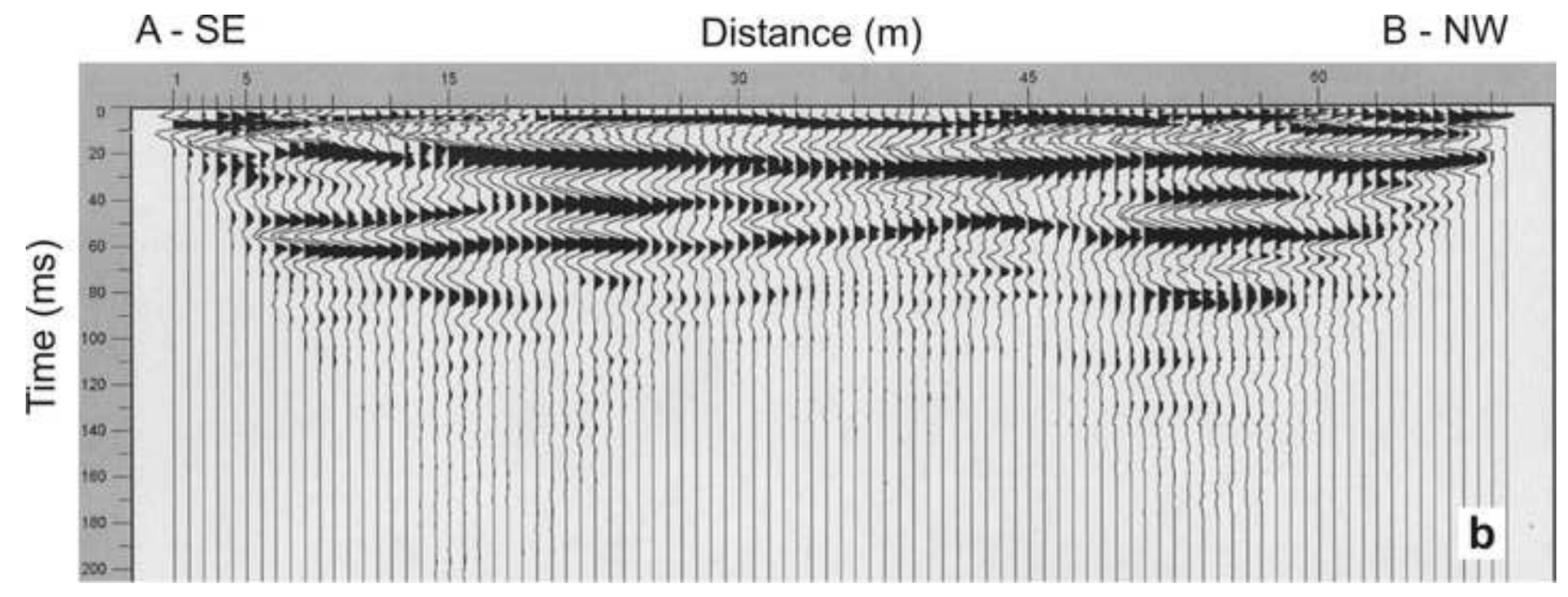


Table 1 Index properties of samples of the clays and silts unit (from 0.5 to $5.9 \mathrm{~m}$ depth in the borehole located on the slope, Figures 7 and 8)

\begin{tabular}{|l|c|c|c|c|c|c|c|c|c|c|}
\hline- & $\begin{array}{c}\mathrm{CaCO}_{3} \\
(\%)\end{array}$ & $\begin{array}{c}\text { Clay } \\
(\%)\end{array}$ & $\begin{array}{c}\text { Silt } \\
(\%)\end{array}$ & $\begin{array}{c}\text { Sand } \\
(\%)\end{array}$ & $\begin{array}{c}\text { Gravel } \\
(\%)\end{array}$ & $\begin{array}{c}\text { Liquid } \\
\text { limit } \\
(\%)\end{array}$ & $\begin{array}{c}\text { Plastic } \\
\text { limit } \\
(\%)\end{array}$ & $\begin{array}{c}\text { Shrinkage } \\
\text { limit } \\
(\%)\end{array}$ & $\begin{array}{c}\text { Plasticity } \\
\text { Index } \\
(\%)\end{array}$ & $\begin{array}{c}\text { Dry specific } \\
\text { weight } \\
\left(\mathrm{kN} / \mathrm{m}^{3}\right)\end{array}$ \\
\hline Slide clay 1 & 5.4 & 25.4 & 64.2 & 7.8 & 2.6 & 55 & 18 & 10 & 37 & 20.209 \\
\hline Top clay 2 & 6.8 & - & - & - & - & 53 & 21 & 11 & 32 & 19.816 \\
\hline Lower clay 3 & 7.9 & - & - & - & - & 57 & 23 & 10 & 34 & 18.149 \\
\hline
\end{tabular}

